\title{
Intranasal Drug Delivery: How, Why and What for?
}

\author{
Anaísa Pires $^{1,2}$, Ana Fortuna ${ }^{1,2}$, Gilberto Alves ${ }^{2,3}$ and Amílcar Falcão ${ }^{1,2}$ \\ 1 Pharmacology Department, Faculty of Pharmacy, University of Coimbra, Coimbra, Portugal. ${ }^{2}$ Centre for \\ Neurosciences and Cell Biology, University of Coimbra, Coimbra, Portugal. ${ }^{3}$ Health Sciences Research Centre \\ (CICS), Faculty of Health Sciences, University of Beira Interior, Covilhã, Portugal.
}

Received, May 4, 2009, Revised, September 17, 2009; Accepted, October 7, 2009, Published, October 8, 2009.

\begin{abstract}
Over the recent decades the interest in intranasal delivery as a non-invasive route for drugs is increased. Since the nasal mucosa offers numerous benefits as a target tissue for drug delivery, a wide variety of therapeutic compounds may be administered intranasally for topic, systemic and central nervous system action. We have, herein, outlined the relevant aspects of nasal anatomy, physiology and histology, and the biological, physicochemical and pharmaceutical factors that must be considered during the process of discovery and development of nasal drugs as well as in their incorporation into appropriate nasal pharmaceutical formulations.
\end{abstract}

\section{INTRODUCTION}

Oral drug delivery is the most desirable route for drug administration whenever systemic effects are intended. Therefore, it is not surprising that the prediction of human oral bioavailability of new drug candidates is currently targeted from the earliest stages of drug discovery and development programmes $(1,2)$. However, although the oral route remains the most popular for systemic drug administration, low oral bioavailability of some compounds has prompted the search of more effective routes for their systemic delivery (3).

Intranasal drug delivery is now recognized to be a useful and reliable alternative to oral and parenteral routes. Undoubtedly, the intranasal administration of medicines for the symptomatic relief and prevention or treatment of topical nasal conditions has been widely used for a long period of time. However, recently, the nasal mucosa has seriously emerged as a therapeutically viable route for the systemic drug delivery. In general, among the primary targets for intranasal administration are pharmacologically active compounds with poor stability in gastrointestinal fluids, poor intestinal absorption and/or extensive hepatic first-pass elimination, such as peptides, proteins and polar drugs (4). The nasal delivery seems to be a favourable way to circumvent the obstacles for blood-brain barrier (BBB) allowing the direct drug delivery in the biophase of central nervous system (CNS)-active compounds. It has also been considered to the administration of vaccines (5-8).
The widespread interest in intranasal route for therapeutic purposes other than the topically nasal drug delivery arises from the particular anatomical, physiological and histological characteristics of the nasal cavity, which provides potential for rapid systemic drug absorption and quick onset of action. In addition, intranasal absorption avoids the gastrointestinal and hepatic presystemic metabolism, enhancing drug bioavailability in comparison with that obtained after gastrointestinal absorption $(9,10)$. On the other hand, intranasal administration also offers several practical advantages either from the viewpoint of patients (non-invasiveness, essentially painless, ease drug delivery and favourable tolerability profile) or pharmaceutical industry (unnecessary sterilization of nasal preparations) $(11,12)$. Hence, bearing in mind the intrinsic value of intranasal route to overcome patient compliance concerns together with its pharmacokinetic advantages, it appears to be an appropriate route for the treatment of not only acute or chronic nasal diseases, but also for a range of acute or chronic conditions requiring considerable systemic drug exposure $(4,12)$.

Corresponding Author: Amílcar Falcão, PharmD, Ph.D, Pharmacology Department, Faculty of Pharmacy, University of Coimbra, Pólo das Ciências da Saúde, Azinhaga de Santa Comba, 3000-548 Coimbra, Portugal, Email: acfalcao@fff.uc.pt 
Despite its advantages, the nasal drug administration presents some limitations that must be considered during the discovery of new chemical entities intended for nasal therapy as well as during the development of nasal formulations. First of all, in addition to physicochemical properties of drugs and characteristics of their final formulations, a variety of physiological and pathological conditions related to nasal mucosa may also compromise the extent of nasal drug absorption and therapy efficacy $(7,11,13)$. Furthermore, the low volume of nasal cavity restricts the amount of drug formulation administered to about 100-150 $\mu \mathrm{L}$ (13). Consequently, particular problems may appear if nasal delivery of high doses of poorly water-soluble drugs is necessary. Nevertheless, these drawbacks are often overcome making use of medicinal chemistry and/or pharmaceutical technology-strategies involving for instance the synthesis of prodrugs and/or the use of enhancers or bioadhesive polymers to increase drug permeability and residence time in nasal cavity. Enzymatic inhibitors may also be employed to protect drugs against enzymatic degradation in the nasal mucosa. However, care should be taken in the use of such compounds due to their possible risks to develop nasal irritation and/or systemic toxic effects (14).

In the last few years a number of excellent reviews have been published examining in detail some particular aspects concerning to potential therapeutic applications of intranasal route of drug delivery (15-23). However, general reviews gathering together information about special characteristics of nasal mucosa, desirable physicochemical properties of drugs for nasal administration and successful technologystrategies to develop pharmaceutical formulations for topically or systemically intranasal drug delivery are lacking. Accordingly, the present review outlines anatomical, physiological and histological features of nasal cavity and the major factors affecting nasal drug delivery, highlighting simultaneously the properties of drugs and formulation characteristics that determine decisively the pharmacokinetics of nasal preparations. Additionally, the rationale for the extensive research of nasal medicines with current and future drug therapies, as well as their therapeutic benefit, will be also considered whenever appropriated.

\section{NASAL CAVITY: ANATOMY, PHYSIOLOGY AND HISTOLOGY}

In humans and other animal species the major functions of the nasal cavity are breathing and olfaction (24). However, it also affords an important protective activity once it filters, heat and humidify the inhaled air before reaching the lowest airways. Nasal cavity is lined with mucus layer and hairs which are involved in those functions, trapping inhaled particles and pathogens. Moreover, resonance of produced sounds, mucociliary clearance MMC, immunological activities and metabolism of endogenous substances are also essential functions of nasal structures (25-28).

Anatomic and histological characteristics of the different areas of nasal cavity are such that allow these functions to be performed optimally. Thus, anatomically, human nasal cavity fills the space between the base of the skull and the roof of the mouth; above, it is supported by the ethmoid bones and, laterally, by the ethmoid, maxillary and inferior conchae bones (25). The human nasal cavity has a total volume of $15-20$ $\mathrm{mL}$ and a total surface area of approximately 150 $\mathrm{cm}^{2}(10,29)$. It is divided by middle (or nasal) septum into two symmetrical halves, each one opening at the face through nostrils and extending posterior to the nasopharynx. Both symmetrical halves consist of four areas (nasal vestibule, atrium, respiratory region and olfactory region) that are distinguished according to their anatomic and histological characteristics (Figure 1; Table $1)$.

\subsection{Nasal vestibule}

Nasal vestibule is the most anterior part of the nasal cavity, just inside the nostrils, and presents an area about $0.6 \mathrm{~cm}^{2}$ (4). Here, there are nasal hairs, also called vibrissae, which filter the inhaled particles. Histologically, this nasal portion is covered by a stratified squamous and keratinized epithelium with sebaceous glands (4, 27, 28). These nasal vestibular characteristics are desirable to afford high resistance against toxic environmental substances but, at the same time, the absorption of substances including drugs becomes very difficult in this region (30). 


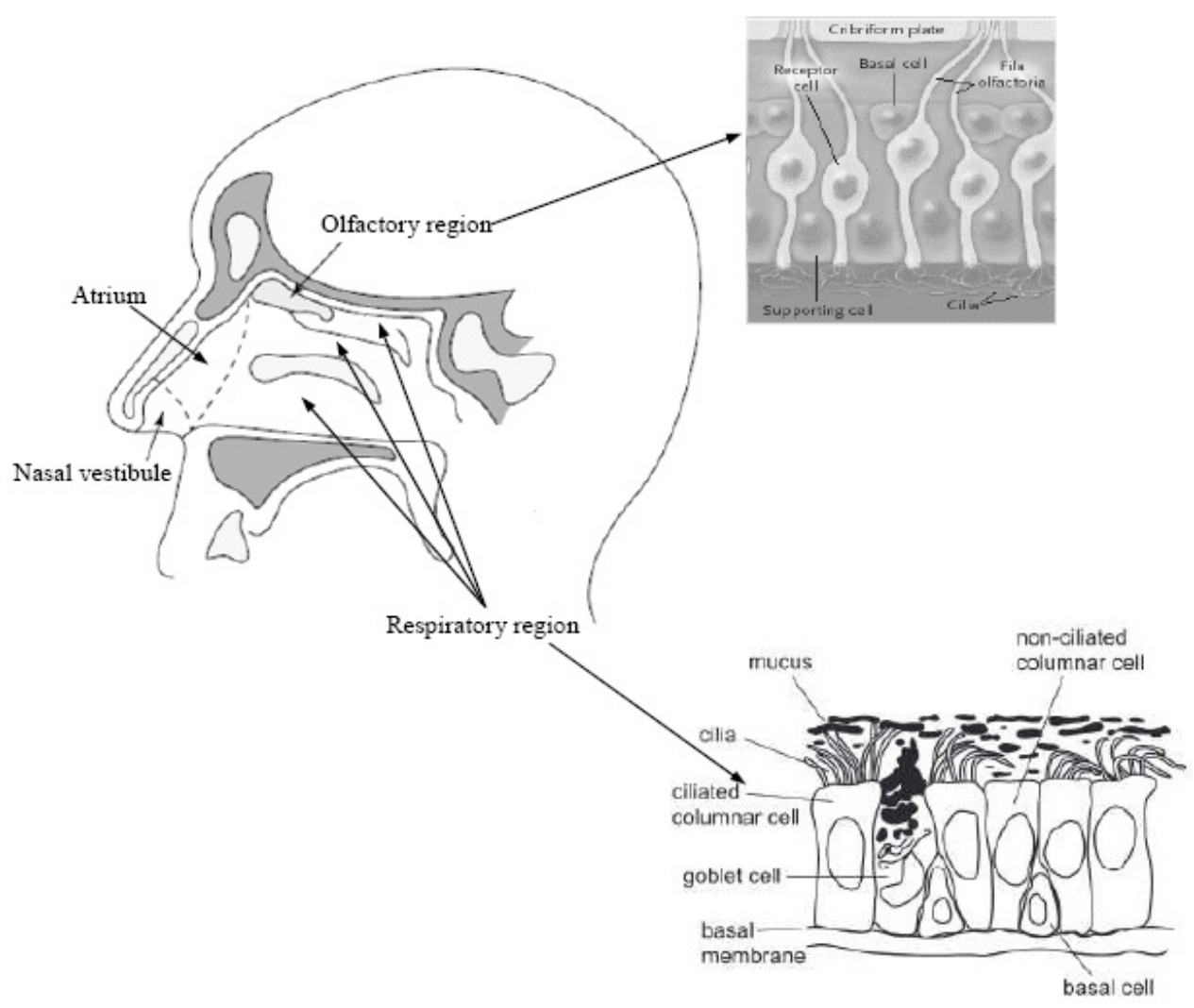

Figure 1. Anatomy and histology of human nasal cavity.

Table 1. Human nasal epithelium characteristics (4, 10, 27, 35).

\begin{tabular}{|c|c|c|c|c|}
\hline $\begin{array}{l}\text { Nasal } \\
\text { Sections }\end{array}$ & $\begin{array}{l}\text { Epithelial Characteristics } \\
\text { Cells / Functions }\end{array}$ & $\begin{array}{l}\text { Surface } \\
\text { Area }\end{array}$ & Vascularization & Permeability \\
\hline Vestibule & $\begin{array}{l}\text { - Stratified squamous and keratinized } \\
\text { epithelial cells with nasal hairs / Support } \\
\text { and protection }\end{array}$ & $\approx 0.6 \mathrm{~cm}^{2}$ & Low & Poor \\
\hline Atrium & $\begin{array}{l}\text { - Stratified squamous cells / Support } \\
\text { - Pseudostratified cells / Support }\end{array}$ & $\mathrm{NF}$ & Low & Reduced \\
\hline $\begin{array}{l}\text { Respiratory } \\
\text { region }\end{array}$ & $\begin{array}{l}\text { - Columnar non ciliated cells / Support } \\
\text { - Columnar ciliated cells / Support and } \\
\text { muciliary clearance } \\
\text { - Globet cells / Mucus secretion } \\
\text { - Basal cells / Progenitors of other cell } \\
\text { types }\end{array}$ & $\approx 130 \mathrm{~cm}^{2}$ & Very high & Good \\
\hline $\begin{array}{l}\text { Olfactory } \\
\text { region }\end{array}$ & $\begin{array}{l}\text { - Sustentacular cells / Support and synthetic } \\
\text { - Olfactory receptor cells / Olfaction } \\
\text { perception } \\
\text { - Basal cells / Progenitors of other cell } \\
\text { types }\end{array}$ & $\approx 15 \mathrm{~cm}^{2}$ & High & $\begin{array}{l}\text { Direct access } \\
\text { to CNS }\end{array}$ \\
\hline
\end{tabular}




\subsection{Atrium}

Atrium is the intermediate area between nasal vestibule and respiratory region. Its anterior section is constituted by a stratified squamous epithelium and the posterior area by pseudostratified columnar cells presenting microvilli $(27,28)$.

\subsection{Respiratory region}

The nasal respiratory region, also called conchae, is the largest part of the nasal cavity and it is divided in superior, middle and inferior turbinates which are projected from the lateral wall. These specialized structures are responsible for humidification and temperature regulation of inhaled air. Between them there are spaces, called meatus, which are passageways where airflow is created to assure a close contact of the inhaled air with the respiratory mucosal surface. The inferior and middle meatus receive nasolacrimal ducts and paranasal sinuses which are air-filled pockets located inside the bones of the face and around the nasal cavity (31).

The nasal respiratory mucosa, considered the most important section for delivering drugs systemically, is constituted by the epithelium, basement membrane and lamina propria. The nasal respiratory epithelium consists of pseudostratified columnar epithelial cells, globet cells, basal cells and mucous and serous glands $(25,27,28)$. Many of the epithelial cells are covered on their apical surface with microvilli and the major part of them also has fine projections, called cilia (28). Actually, microvilli are important to enhance the respiratory surface area, while cilia are essential to transport the mucus toward the nasopharynx. Under physiological conditions, nasal epithelium is covered with a thin mucus layer produced by secretory glands and globet cells. These ones secrete granules filled with mucin, a glycoprotein that determines the viscosity of the mucus. The nasal mucus layer is only $5 \mu \mathrm{m}$ thick and it is organized in two distinct layers: an external, viscous and dense, and an internal, fluid and serous. Overall, nasal mucus layer consists of $95 \%$ of water, $2.5-3 \%$ of mucin, and $2 \%$ of electrolytes, proteins, lipids, enzymes, antibodies, sloughed epithelial cells and bacterial products (32-34). Nasal mucus is indispensable for several physiological functions, such as humidification and warming of the inhaled air, and also offers physical and enzymatic protection of the nasal epithelium against several foreign compounds, including drugs. The protective action results of the adhesive characteristics of mucus to attract inhaled particles or pathogens, which are removed towards the nasopharynx by nasal MCC (35). The presence of mucin in the nasal mucus layer is crucial because it may trap large molecular weight drugs, such as peptides and proteins (13). The basal cells that exist in the epithelium are progenitors of other cell-types and lye on a thickened layer of collagen called basement membrane. Beneath of it, there is the lamina propria which is richly supplied with blood vessels, including many very permeable fenestrated capillaries, nerves, glands and immune cells. The last ones produce immunoglobulin A antibodies that confer immunological protection against bacteria and virus (36).

\subsection{Olfactory region}

The olfactory region is located in the roof of the nasal cavity and extends a short way down the septum and lateral wall (27). Its neuroepithelium is the only part of the CNS that is directly exposed to the external environment (37). Similarly to the respiratory epithelium, the olfactory one is also pseudostratified but contains specialized olfactory receptor cells important for smell perception $(27,37)$. In this area there are also small serous glands (glands of Bowman) producers of secretions acting as a solvent for odorous substances (27).

\section{INTRANASAL DRUG DELIVERY}

Over the last years, due to the understanding of the positive attributes and appropriate characteristics of the nasal cavity, intranasal route has been increasingly considered for drug delivery when developing new chemical entities or improving the therapeutic profile of existing drugs. However, to assess the therapeutic viability of intranasal drug delivery several approaches should be considered, attending, specifically, to the nature of pathologic condition (acute or chronic) and intended effects of drug treatment (local, systemic or at CNS). Indeed, for acute disease conditions, the advantages afforded by intranasal drug delivery in terms of patient comfort and compliance may not be much relevant when compared with drug delivery by parenteral route. In contrast, this is particularly 
important to treat or control chronic medical conditions (38).

\subsection{Local delivery}

Intranasal administration of medicines is the natural choice for the treatment of topical nasal disorders. Among the most common examples are antihistamines and corticosteroids for rhinosinusitis, and nasal decongestants for cold symptoms (Table 2). In these cases, intranasal route is the primary option for drug delivery because it allows a rapid symptom relief with a more favourable adverse-event profile than oral or parenteral routes. In fact, relatively low doses are effective when administered topically (40), minimizing simultaneously the potential of systemic toxic effects. Recently, for instance, topical antibiotherapy has been considered in chronic rhinosinusitis in an attempt to eradicate biofilm bacteria, often resistant to systemic treatment, and still avoiding systemic toxicity (4146).

\subsection{Systemic delivery}

The intranasal administration is an effective way to systemically delivery of drugs as an alternative to oral and intravascular routes. Actually, it seems to present fast and extended drug absorption (47), and it has been supported by many studies planned to compare intranasal drug delivery against oral and parenteral administration (Figure 2) $(9,49,50)$. Consequently, the number of drugs administered as nasal formulations intended to achieve systemic effects has widely increased. Some prominent examples include analgesics (morphine) $(4,7,51)$, cardiovascular drugs as propranolol (52) and carvedilol (53), hormones such as levonorgestrel (48), progesterone (54) and insulin $(49,55-57)$, anti-inflammatory agents as indomethacin $(58,59)$ and ketorolac $(60,61)$, and antiviral drugs (acyclovir) (62-65). Actually, there are some examples already available in the market (Table 2). These include, for instance, zolmitriptan and sumatriptan for the treatment of migraine and cluster headaches.

\subsection{Nasal vaccines}

Nasal mucosa is the first site of contact with inhaled antigens $(4,13)$ and, therefore, its use for vaccination, especially against respiratory infections, has been extensively evaluated. In fact, nasal vaccination is a promising alternative to the classic parenteral route, because it is able to enhance the systemic levels of specific immunoglobulin $G$ and nasal secretory immunoglobulin A $(58,66-68)$. In upper airways, the systemic and local immunological responses are mainly mediated by the nasal associated lymphoid tissue situated underneath the nasal epithelium. The nasal associated lymphoid tissue is composed of agglomerates of dendritic cells, Tcells and B-cells which are involved in the initiation and execution of immune responses (68). Examples of the human efficacy of intranasal vaccines include those against influenza $\mathrm{A}$ and B virus, proteosoma-influenza (69), adenovirus-vectored influenza (70), group B meningococcal native (71), attenuated respiratory syncytial virus (72) and parainfluenza 3 virus (72, 73) (Table 2). However, human nasal vaccination is not restricted to the upper airways affections. After nasal immunization secretory immunoglobulin A can also be detected in other mucosal secretions, which may be important against virus transmitted through other mucosal sites, such as human immunodeficiency virus (74) and hepatitis B virus (75).

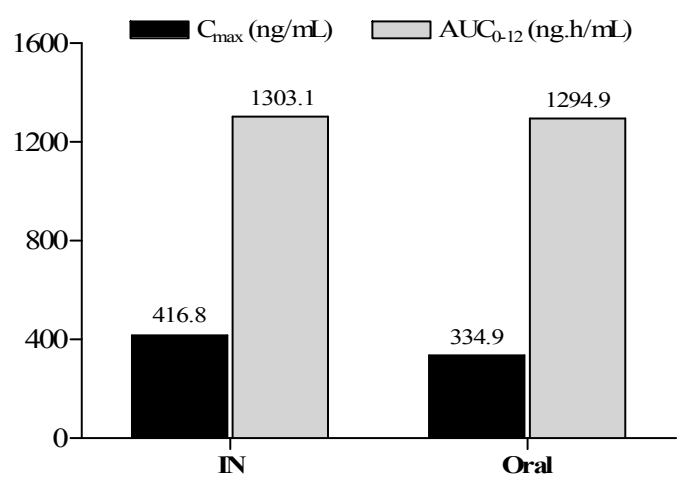

Figure 2. Plasma pharmacokinetic parameters obtained after intranasal (IN) and oral administration of levonorgestrel $(500 \mu \mathrm{g})$ in rats $(48)$. 
Table 2. Examples of nasal formulations commercially available after prescription $(4,6,13,39)$.

\begin{tabular}{|c|c|c|c|c|}
\hline Drug & Brand & Main Excipients & Supplier & Main Indications \\
\hline \multicolumn{5}{|c|}{ Local Delivery } \\
\hline Azelastine & Astelin & $\begin{array}{l}\text { Benzalkonium chloride, } \\
\text { edetate disodium, } \\
\text { hypromellose }\end{array}$ & Meda Pharmaceuticals & \\
\hline Beclometasone & Beconase & $\begin{array}{l}\text { Microcrystalline cellulose, } \\
\text { carboxymethyl cellulose } \\
\text { sodium, } \\
\text { benzalkonium chloride }\end{array}$ & GlaxoSmithKline & \\
\hline Budesonide & Rhinocort & $\begin{array}{l}\text { Microcrystalline cellulose, } \\
\text { carboxymethyl cellulose } \\
\text { sodium, dextrose anhydrous }\end{array}$ & AstraZeneca & \\
\hline Levocabastine & Livostin & $\begin{array}{l}\text { Benzalkonium chloride, } \\
\text { edetate disodium, disodium } \\
\text { phosphate }\end{array}$ & Jansen-Cilag & $\begin{array}{l}\text { Management/treat } \\
\text { ment of symptoms } \\
\text { of seasonal and }\end{array}$ \\
\hline Mometasone & Nasonex & $\begin{array}{l}\text { Microcrystalline cellulose, } \\
\text { carboxymethylcellulose } \\
\text { sodium, benzalkonium } \\
\text { chloride }\end{array}$ & Schering-Plough & $\begin{array}{l}\text { perennial rhino- } \\
\text { sinusitis }\end{array}$ \\
\hline Olapatadine & Patanase & $\begin{array}{l}\text { Benzalkonium chloride, } \\
\text { dibasic sodium phosphate, } \\
\text { edetate disodium }\end{array}$ & Alcon Laboratories & \\
\hline $\begin{array}{l}\text { Sodium } \\
\text { cromoglicate }\end{array}$ & Nasalcrom & $\begin{array}{l}\text { Benzalkonium chloride, } \\
\text { edetate disodium }\end{array}$ & Sanofi-Aventis & \\
\hline $\begin{array}{l}\text { Triamcinolone } \\
\text { acetonide }\end{array}$ & Nasacort & $\begin{array}{l}\text { Microcrystalline cellulose, } \\
\text { carboxymethylcellulose } \\
\text { sodium, polysorbate } 80\end{array}$ & Sanofi Aventis & \\
\hline Mupirocin & Bactroban & $\begin{array}{l}\text { Paraffin and a mixture of } \\
\text { glycerin esters (Softisan 649) }\end{array}$ & GlaxoSmithKline & $\begin{array}{l}\text { Eradication of nasal } \\
\text { staphylococci }\end{array}$ \\
\hline \multicolumn{5}{|c|}{ Systemic Delivery } \\
\hline Estradiol & Aerodiol & $\begin{array}{l}\text { Methylbetadex, sodium } \\
\text { chloride }\end{array}$ & Servier laboratories & $\begin{array}{l}\text { Hormone } \\
\text { replacement } \\
\text { therapy }\end{array}$ \\
\hline Nicotine & Nicotrol NS & $\begin{array}{l}\text { Disodium phosphate, } \\
\text { sodium dihydrogen } \\
\text { phosphate, citric acid }\end{array}$ & Pfizer & Smoking cessation \\
\hline Cyanocobalamin & Nascobal & $\begin{array}{l}\text { Sodium citrate, citric acid, } \\
\text { benzalkonium chloride }\end{array}$ & $\begin{array}{l}\text { Strativa } \\
\text { pharmaceuticals }\end{array}$ & $\begin{array}{l}\text { Vitamin } \mathrm{B}_{12} \\
\text { deficiency }\end{array}$ \\
\hline Desmopressin & Desmospray & $\begin{array}{l}\text { Sodium chloride, citric } \\
\text { acid, benzalkonium } \\
\text { chloride }\end{array}$ & $\begin{array}{l}\text { Ferring } \\
\text { Pharmaceuticals }\end{array}$ & $\begin{array}{l}\text { Control of } \\
\text { dehydration in } \\
\text { diabetes insipidus }\end{array}$ \\
\hline Oxytocin & Syntocinon & $\begin{array}{l}\text { Citric acid, chlorobutanol, } \\
\text { sodium chloride }\end{array}$ & Novartis & $\begin{array}{l}\text { Labour induction; } \\
\text { lactation } \\
\text { stimulation }\end{array}$ \\
\hline $\begin{array}{l}\text { Salmon } \\
\text { calcitonin }\end{array}$ & Miacalcin & $\begin{array}{l}\text { Sodium chloride, } \\
\text { benzalkonium chloride, } \\
\text { hydrochloric acid }\end{array}$ & Novartis & $\begin{array}{l}\text { Treatment of post- } \\
\text { menopausal } \\
\text { osteoporosis }\end{array}$ \\
\hline
\end{tabular}


Table 2 continued.....

\begin{tabular}{|c|c|c|c|c|}
\hline Buserelin & Suprefact & $\begin{array}{l}\text { Sodium hydroxide, sodium } \\
\text { chloride, sodium } \\
\text { dihydrogen phosphate }\end{array}$ & Sanofi-Aventis & $\begin{array}{l}\text { Treatment of } \\
\text { prostate cancer }\end{array}$ \\
\hline Nafarelin & Synarel & $\begin{array}{l}\text { Benzalkonium chloride, } \\
\text { glacial acetic acid }\end{array}$ & Roche Laboratories & $\begin{array}{l}\text { Management of } \\
\text { endometriosis }\end{array}$ \\
\hline Zolmitriptan & Zomig & Citric acid, disodium & AstraZeneca & \\
\hline Sumatriptan & Imigran & $\begin{array}{l}\text { Potassium dihydrogen } \\
\text { phosphate, dibasic sodium } \\
\text { phosphate anhydrous }\end{array}$ & GlaxoSmithKline & $\begin{array}{l}\text { Treatment of } \\
\text { migraine and } \\
\text { cluster headaches }\end{array}$ \\
\hline Fentanyl & Instany & $\begin{array}{l}\text { Sodium dihydrogen } \\
\text { phosphate dehydrate, } \\
\text { disodium phosphate }\end{array}$ & Nycomed Pharma & \\
\hline Butorphanol & Stadol NS & $\begin{array}{l}\text { dehydrate } \\
\text { Sodium chloride, citric } \\
\text { acid, benzethonium } \\
\text { chloride }\end{array}$ & Bristol-Myers Squibb & Pain management \\
\hline $\begin{array}{l}\text { Live attenuated } \\
\text { influenza } \\
\text { vaccine }\end{array}$ & FluMist & $\begin{array}{l}\text { Monosodium glutamate, } \\
\text { hydrolyzed porcine gelatin, } \\
\text { arginine, dibasic potassium } \\
\text { phosphate, monosodium } \\
\text { phosphate, gentamicin } \\
\text { sulfate }\end{array}$ & MedImmune, Inc. & Flu prevention \\
\hline
\end{tabular}

\subsection{CNS delivery through nasal route}

The brain is a delicate organ with many vital functions and it is isolated and protected from the outside environment by several intriguing mechanisms. Unfortunately, those are the same mechanisms that prevent the CNS delivery of therapeutic agents. The tight junctions of the BBB surrounding the brain is one of such mechanisms (8), resulting in a greater transendothelial electric

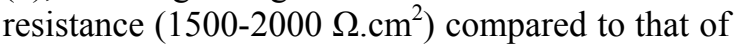
other tissues like skin, bladder, colon, lungs (3-33 $\Omega . \mathrm{cm}^{2}$ ) (76). This histological organization impairs, therefore, the systemically delivery of CNS-active drugs. Even though, if drugs or other xenobiotics pass through the BBB, a second line of defence mechanisms, including multidrug efflux protein transporters, may reduce the brain exposure. It is estimated that almost half of drug candidates are substrates to P-glycoprotein (P-gp) efflux pump, presenting reduced potential for systemically CNS penetration $(77,78)$.

The obstacle imposed by those brain protective mechanisms has increased the interest in developing strategies to overcome them when brain drug exposure is required. In this context, over the last few years, intranasal route has emerged as a promising approach for brain delivery of drugs. The delivery from the nose to the CNS may occur via olfactory neuroepithelium and may involve paracellular, transcellular and/or neuronal transport $(4,75,79)$. Although the olfactory pathway presents potential to bypass BBB, P-gp appears to be also functional on this area $(8,76,80-82)$. Graff et al. (81) confirmed that P-gp is present in both the olfactory epithelium and endothelial cells that surround the olfactory bulb. Moreover, the transport via trigeminal nerve system from the nasal cavity to CNS has also been described (83).

Drug delivery into CNS through intranasal route has been reported (84-87) either in humans or animal models of Alzheimer's disease $(88,89)$, brain tumours $(90,91)$, epilepsy (92), pain (82) and sleep disorders (93). However, it should be noted that in other cases evidence is lacking supporting the greater brain exposure via intranasal delivery despite the needless of passage BBB and the absence of gastrointestinal and hepatic presystemic elimination (94-97). 


\section{FACTORS INFLUENCING NASAL DRUG ABSORPTION}

When a drug is nasally administered to induce systemic effects or to act into CNS it needs to pass through the mucus layer and epithelial membrane before reaching the blood stream or pass directly to the CNS. The passage across the epithelium may occur by transcellular or paracellular mechanisms. The first one includes passive diffusion through the interior of the cell and it is especially involved in the transport of lipophilic drugs (11). However, it seems that compounds with a molecular weight higher than 1 $\mathrm{kDa}$, such as peptides and proteins, are transcellularly transported by endocytic processes $(13,35)$. Furthermore, transcellular transport can be mediated by carriers that exist in the nasal mucosa, including organic cation transporters and amino acids transporters $(76,80-82)$. In contrast, paracellular route is involved in the transport of small polar drugs and it takes place between adjacent epithelial cells through hydrophilic porous and tight junctions. Tight junctions are dynamic structures localized between the cells, which open and close accordingly to (in)activation of signalling mechanisms. Nevertheless, it is well known that their size is comprised between 3.9-8.4 $\AA$ (98), avoiding the passage of bigger molecules, being this process of transport highly dependent of drug molecular weight (99).

Taking into account previous considerations, it is evident that the molecular weight and lipophilicity of drugs may have a great impact in the rate and extent of its nasal absorption. However, other physicochemical drug properties must be considered as well as the characteristics of drug formulation $(7,11,13)$. In this section all these factors will be discussed after a review of the influence of nasal physiological factors on nasal drug absorption.

\subsection{Nasal physiological factors}

\subsubsection{Blood flow}

Nasal mucosa is richly supplied with blood and presents a large surface area making it an optimal local for drug absorption. The blood flow rate influences significantly the systemic nasal absorption of drugs, so that as it enhances more drug passes through the membrane, reaching the general circulation. Indeed, bearing in mind that most of drug absorption takes place by diffusion, the blood flow is essential to maintain the gradient of concentration from the site of absorption to blood. Hence, it is well known that vasodilatation and vasoconstriction may determine the blood flow and, consequently, the rate and extent of drug to be absorbed. Several studies were made to evaluate this influence. For example, Huang et al. (100) showed that phenylephrine, a vasoconstrictor agent, inhibited the absorption of acetylsalicylic acid in nasal cavity. More recently, Kao et al. (101) stated that nasal absorption of dopamine was relatively slow and incomplete probably due to its own vasoconstrictor effect. Based on these observations, it was concluded that vasoconstriction decrease nasal drug absorption by diminishing the blood flow.

\subsubsection{Mucociliary clearance}

MMC also referred to as mucociliary apparatus or mucociliar clearance (MCC) is the self-clearing mechanism of the bronchi. Nasal mucus layer plays an important role in the defence of respiratory tract because it prevents the lungs from foreign substances, pathogens and particles carried by inhaled air. These agents adhere to the mucus layer and, all together, they are transported to the nasopharynx and, eventually, to the gastrointestinal tract. This elimination is designated MCC and it influences also significantly the nasal drug absorption. The MCC system has been described as a "conveyer belt" wherein cilia provide the driving force whereas mucus acts as a sticky fluid that collects and disposes foreign particles (28). The efficiency of MCC thereby depends on the length, density and beat frequency of cilia as so as the amount and viscoelastic properties of mucus. Briefly, all factors that increase mucus production, decrease mucus viscosity or increase ciliary beat frequency may increase the MCC.

In physiological conditions, mucus is transported at a rate of $5 \mathrm{~mm} / \mathrm{min}$ and its transit time in human nasal cavity is reported to be $15-20$ $\min (4,35)$. Values out of these references are abnormal and suggestive of impaired MCC (28). Thus, if MCC decreases, residence time of the drug product in nasal mucosa increase and, therefore, enhances its permeation. The opposite effect is observed when MCC increases. In the last case, a premature discharge of nasally administered drugs from nasal cavity toward the 
nasopharynx occurs, decreasing the amount of drug absorbed. The clearance of a drug product from the nasal cavity is also influenced by the site of deposition. A drug deposited in a posterior area of the nose is cleared more rapidly from the nasal cavity than a drug deposited anteriorly. This is because MCC is slower in the anterior part of the nose than in the more ciliated posterior part $(28$, 102). On the other hand, the site of drug deposition in the nose is highly dependent on the dosage form. Nasal sprays deposit drugs more anteriorly than nasal drops, resulting in a slower clearance for drugs administered from spray formulations (4).

Polar drugs are the most affected by MCC, since they are highly soluble in mucus and their passage across the membrane is very slow. Thus, all factors that influence the efficacy and pace of MCC may modify the drug absorption profile. For instance, environmental factors have a relevant influence in MCC. Temperature and sulphur dioxide seem to cause a significant reduction in MCC, but this the mechanism is not well known. Cigarette smoking also decreases $\mathrm{MCC}$ as it enhances the viscosity of the mucus and/or diminishes the number of cilia. In addition, several pathological conditions exist in which MCC does not work properly $(28,103,104)$, as shown in Table 3. Furthermore some components of drug formulations may also alter the MCC system, such as preservatives and nasal absorption enhancers (28). Finally, it is interesting to stand out the inter-individual variability observed in MCC and the influence of the menstrual cycle and circadian rhythm. Actually, during the periovulatory period MCC is increased and it is reduced at night.

\subsubsection{Enzymatic degradation}

Drugs nasally administered circumvent gastrointestinal and hepatic first-pass effect. However, they may be significantly metabolized in lumen of nasal cavity or during the passage across the nasal epithelial barrier due to the presence of a broad range of metabolic enzymes in nasal tissues. Carboxyl esterases, aldehyde dehydrogenases, epoxide hydrolases and gluthatione S-transferases have been found in nasal epithelial cells and are responsible for the degradation of drugs in nasal mucosa (105-107). Cytochrome P450 isoenzymes are also present here and they have been reported as metabolizers of drugs such as cocaine, nicotine, alcohols, progesterone and decongestants $(108,109)$. Similarly, proteolytic enzymes (aminopeptidases and proteases) were found and they are believed to be the major barrier against the absorption of peptide drugs, such as calcitonin, insulin and desmopressin $(110,111)$. Thus, xenobioticmetabolizing enzymes existent in the nasal mucosa may affect the pharmacokinetic and pharmacodynamic profile of nasally applied drugs. In this context, although the nasal first-pass metabolism is usually weaker than hepatic and intestinal ones it cannot be ignored.

\subsubsection{Transporters and efflux systems}

The study of transporter systems present in the nasal tissue and their effects on the absorption of drugs into systemic circulation and CNS is a research area in development.

Table 3. Pathological conditions and their impact in nasal mucociliary clearance $(28,103)$.

\begin{tabular}{ll}
\hline Pathological conditions & Mucociliary clearance \\
\hline Primary ciliary dyskinesia & • Impaired: absence or dyskinetic beating cilia \\
Asthma & • Increased: inflammatory process and irritation \\
& - Decreased: epithelial damage \\
Cystic fibrosis & - Impaired: dehydratation of mucus \\
Viral and bacterial infections & • Compromised: loss of cilia and change of mucus properties \\
Diabetes mellitus & • Impaired: dehydratation and microvascular damage \\
\hline
\end{tabular}




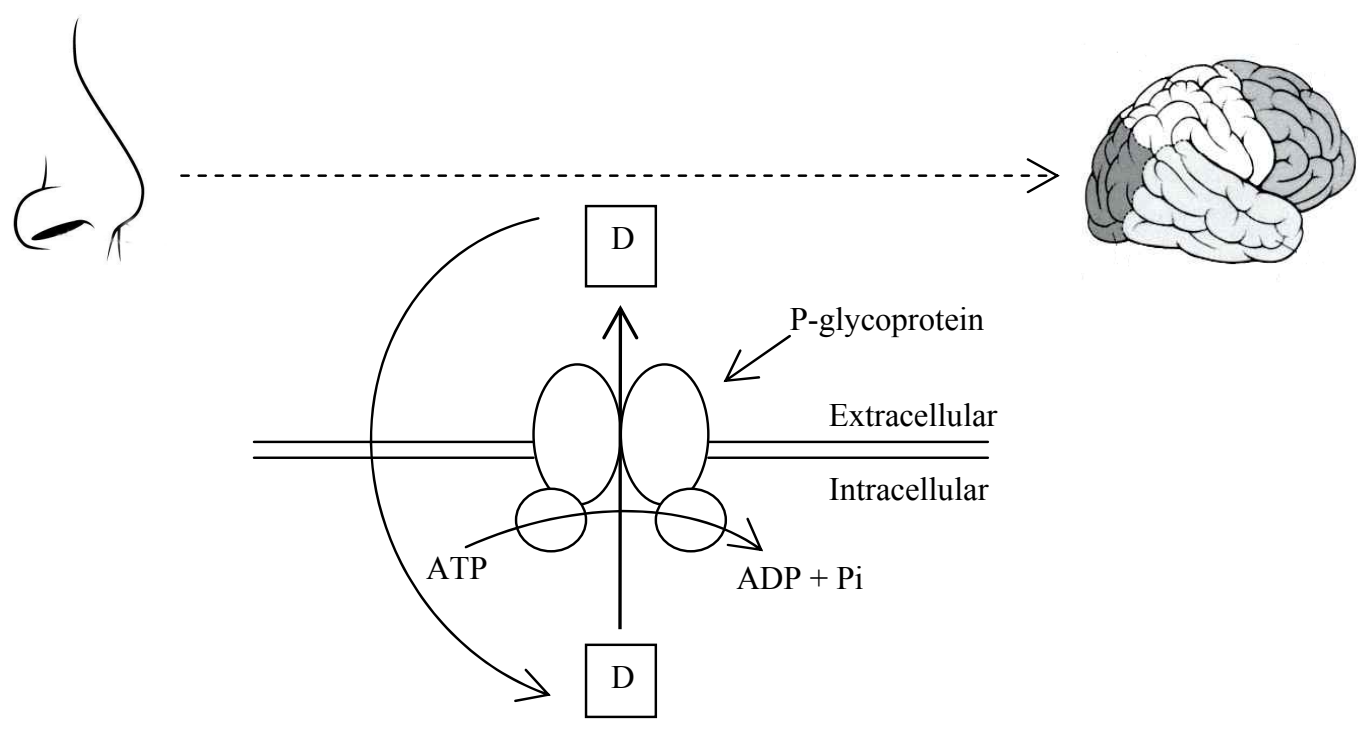

Figure 3. P-glycoprotein, an ATP-dependent efflux pump, preventing the influx of a drug (D) from nasal membrane to CNS.

At the moment, multidrug resistance transporters has already been identified in human nasal respiratory and olfactory mucosa, which may be involved in the transport of a wide variety of hydrophobic and amphiphilic drugs (13). P-gp is an efflux transporter that exists in the apical area of ciliated epithelial cells and in the submucosal vessels of the human olfactory region (81). Several studies $(80-82,112)$ demonstrated that Pgp has an important role in preventing actively the influx of drugs from nasal membrane (Figure 3).

\subsection{Physicochemical properties of drugs}

The influence of physicochemical characteristics of drug molecules on the rate and extent of gastrointestinal absorption is well understood. Therefore, in silico models have been developed to prioritize numerous drug candidates at the early phases of drug discovery. In same way, but with some differences, the physicochemical properties of drugs (molecular weight, lipophilicity, pKa, stability and solubility) can influence nasal absorption.

\subsubsection{Molecular weight, lipophilicity and pKa}

Lipophilic drugs such as propranolol, progesterone and fentanyl are, in general, well absorbed from the nasal cavity, presenting pharmacokinetic profiles similar to those obtained after intravenous administration (Figure 4) and a nasal bioavailability near to $100 \%$. Indeed, they are quickly and efficiently absorbed across the nasal membrane through transcellular mechanisms. However, it is important to state that this is true for lipophilic compounds presenting a molecular weight lower than $1 \mathrm{kDa}$. The extension of nasal absorption of lipophilic drugs bigger than $1 \mathrm{kDa}$ is significantly reduced (99). On the other hand, the rate and degree of nasal absorption of polar drugs is low and highly dependent of the molecular weight. Several studies $(99,114-116)$ demonstrated that the permeation of polar drugs with a molecular weight of less than $300 \mathrm{Da}$ is not considerably influenced by their physicochemical properties. By contrast, the rate of permeation is highly sensitive to molecular size if it is higher than 300 $\mathrm{Da}$; an inverse relationship exists between rate of permeation and molecular weight $(114,115)$. For some small polar molecules only a $10 \%$ bioavailability is suggested. The value goes down to $1 \%$ for large molecules such as proteins (117). The nasal membrane is predominantly lipophilic, hence, drug absorption is expected to diminish with a decrease in lipophilicity $(114,118)$. Thus, it is evident that polar drugs are not easily transported across nasal membrane thereby enhancing MCC. However, if lipophilicity is too high, the drug does not dissolve easily in the aqueous environment of nasal cavity, hence, with 
accelerated MCC the contact time with nasal membrane diminishes resulting in a reduced permeation through the wall (119). In general, the passage across biomembranes is affected not only by lipophilicity/hydrophilicity, but also by the amount of drug existing as uncharged species. This depends on the drug $\mathrm{pKa}$ and the $\mathrm{pH}$ of the absorption site (5.0-6.5 in human nasal mucosa) $(26,35,120)$. According to $\mathrm{pH}$ partition theory, the non-ionized fraction of a drug is more permeable than that ionized. For the nasal mucosa, a range of studies evaluating the effect of lipophilicity and $\mathrm{pH}$ on the absorption of small drugs were performed $(62,118,121-123)$. All of them demonstrated that nasal absorption of weak electrolytes depends on their ionization degree and the largest absorption occurs for the nonionized species. In this state, they present a higher apparent partition coefficient and, thus, they are more lipophilic. However, drugs such as acetylsalicylic acid (121) and benzoic acid (122) showed some permeability across the membrane even in environments that they are expected to exist as the ionized species. Based on these observations, it was concluded that, for polar drugs, partition coefficient is the major factor influencing the permeability through nasal mucosa.

\subsubsection{Stability}

During the development of new drug formulations biological, chemical and physical drug stability studies must be a matter of the major importance in all process. As discussed before, the environment of nasal cavity has the ability to metabolize drugs by defensive enzymatic mechanisms, which may reduce the biological stability of nasally administered drugs (105-107). To overcome this difficulty a variety of strategies may be followed, mainly through the use of prodrugs $(11,13,63,100)$ and enzymatic inhibitors (124-126), as it will be discussed later. On the other hand, many drugs may be physicochemically instable due to hydrolysis, oxidation, isomerisation, photochemical decomposition or polymerization reactions (13). The same holds true during the intranasal drug delivery (6).

\subsubsection{Solubility}

Drug dissolution is a pre-requisite for any drug absorption, since only the molecularly disperse form of a drug at the absorption site may cross the biomembranes. Hence, before nasal absorption the drug must to be dissolved in the watery fluids of the nasal cavity. Thus, of the utmost importance is the appropriated aqueous drug solubility to allow enough contact with the nasal mucosa and posterior absorption (123). However, the absorption profile is influenced not only by drug solubility but also by the nature of pharmaceutical preparations, which have to guarantee the delivery of drug at therapeutically relevant doses. Due to the small size of nasal cavity, the allowable volume of drug solution is low for intranasal drug administration (13).

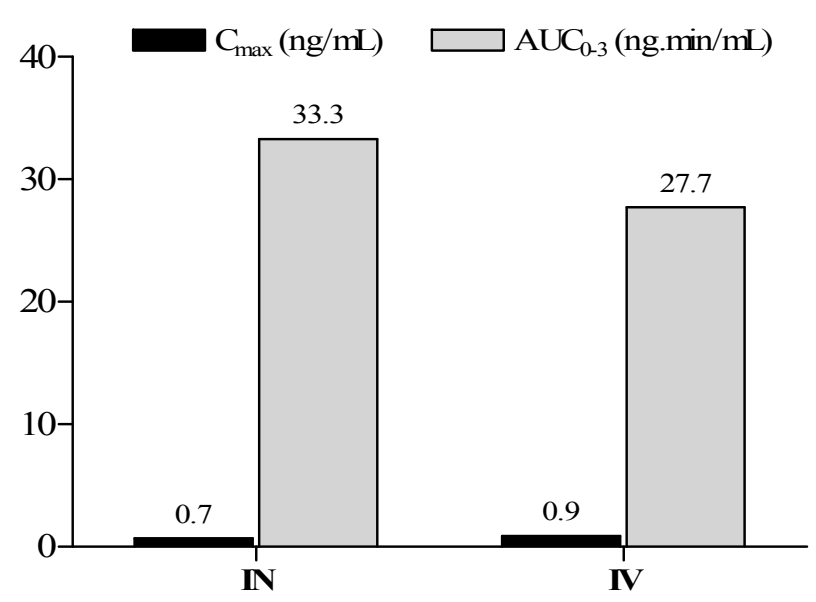

Figure 4. Plasma pharmacokinetic parameters obtained after intranasal (IN) and intravenous (IV) administration of fentanyl $(75 \mu \mathrm{g})$ in man (113). 
Thereby, drugs poorly soluble in water and/or requiring high doses may constitute a problem. This can be overtaken enhancing the drug aqueous solubility $(6,11,13,101,127)$.

\subsection{Effect of drug formulation}

\subsubsection{Viscosity}

As formulation viscosity increases, the contact time between drug and nasal mucosa enhances and, thereby, the potential of drug absorption increases. At the same time, high viscosity of formulations interferes with normal ciliary beating and/or MCC and, thus, increases the permeability of drugs. This has been observed during nasal delivery of insulin (49), acyclovir (65) and metoprolol (52). However, sometimes, enhancing formulation viscosity does not enhance the drug absorption. For example, Zaki et al. (123) performed a study to evaluate the influence of formulation viscosity on the retention time of metoclopramide hydrochloride in nasal cavity and on its absorption. Interestingly, they observed that although the residence time enhanced as viscosity increased the drug absorption diminished. This observation has been attributed to a decrease in the drug diffusion from the formulation. On the other hand, it has also been reported that the viscosity of the solution may provide a larger therapeutic period of nasal formulations (123).

\subsection{2. $\mathrm{pH}$}

The extent of nasal absorption depends on the $\mathrm{pKa}$ of drug and $\mathrm{pH}$ at the absorption site, contributing for that also the $\mathrm{pH}$ of formulation. At this point, it should be stated that the $\mathrm{pH}$ of formulation must be selected attending to drug stability and if possible should be assured the greatest quantity of non-ionized drug species. However, the $\mathrm{pH}$ of formulation can induce nasal mucosa irritation and, hence, it should be similar to that found on human nasal mucosa (5.0-6.5) $(26,35,120)$. Besides, the $\mathrm{pH}$ often prevents the bacteria growth (11). In order to evaluate the effect of $\mathrm{pH}$ solution on the integrity of nasal mucosa, Pujara et al. (128) dissolved drugs in phosphate buffer at different $\mathrm{pH}$ values in the range of 2-12. The study was performed in rats whose nasal $\mathrm{pH}$ is 7.39 (121) and the results demonstrated that when $\mathrm{pH}$ ranged from 3-10 minimal quantities of proteins and enzymes were released from cells, demonstrating no cellular damages. On the contrary, if $\mathrm{pH}$ values were below 3 or above 10 damages were observed intracellularly and at membrane level.

\subsubsection{Pharmaceutical form}

Nasal drops are the simplest and the most convenient nasal pharmaceutical form, but the exact amount of drug delivered is not easily quantified and often results in overdose (6). Moreover, rapid nasal drainage can occur when using this dosage form. Solution and suspension sprays are preferred over powder sprays because the last one easily prompted the development of nasal mucosa irritation (104). Recently, geldevices have been developed for a more accurate drug delivery. They reduce postnasal drip and anterior leakage, fixing the drug formulation in nasal mucosa. This enhances the drug residence time and diminishes MCC, thereby, potentially increases the nasal absorption. Over the last years, specialized systems such as lipid emulsions, microspheres, liposomes and films have also been developed to improve nasal drug delivery.

\subsubsection{Pharmaceutical excipients}

In nasal formulations, a wide variety of pharmaceutical excipients can be found and they are selected accordingly to their functions. Solubilizers, buffer components, antioxidants, preservatives, humectants, gelling/viscosifying agents, and flavoring or taste masking agents are some of the most usual excipients (6). Although they are responsible for several nasal irritations, antioxidants, preservatives, humectants and flavoring or taste masking agents are not expected to alter nasal drug absorption (6).

\section{STRATEGIES TO INCREASE NASAL DRUG ABSORPTION}

Although the intranasal route is efficient for topic, systemic and CNS delivery of a wide range of drugs, it cannot be applied for many others due to their low nasal bioavailability. Briefly, bioavailability of nasally administered drugs is particularly restricted by low drug solubility, rapid enzymatic degradation in nasal cavity, poor membrane penetration and rapid MCC. 


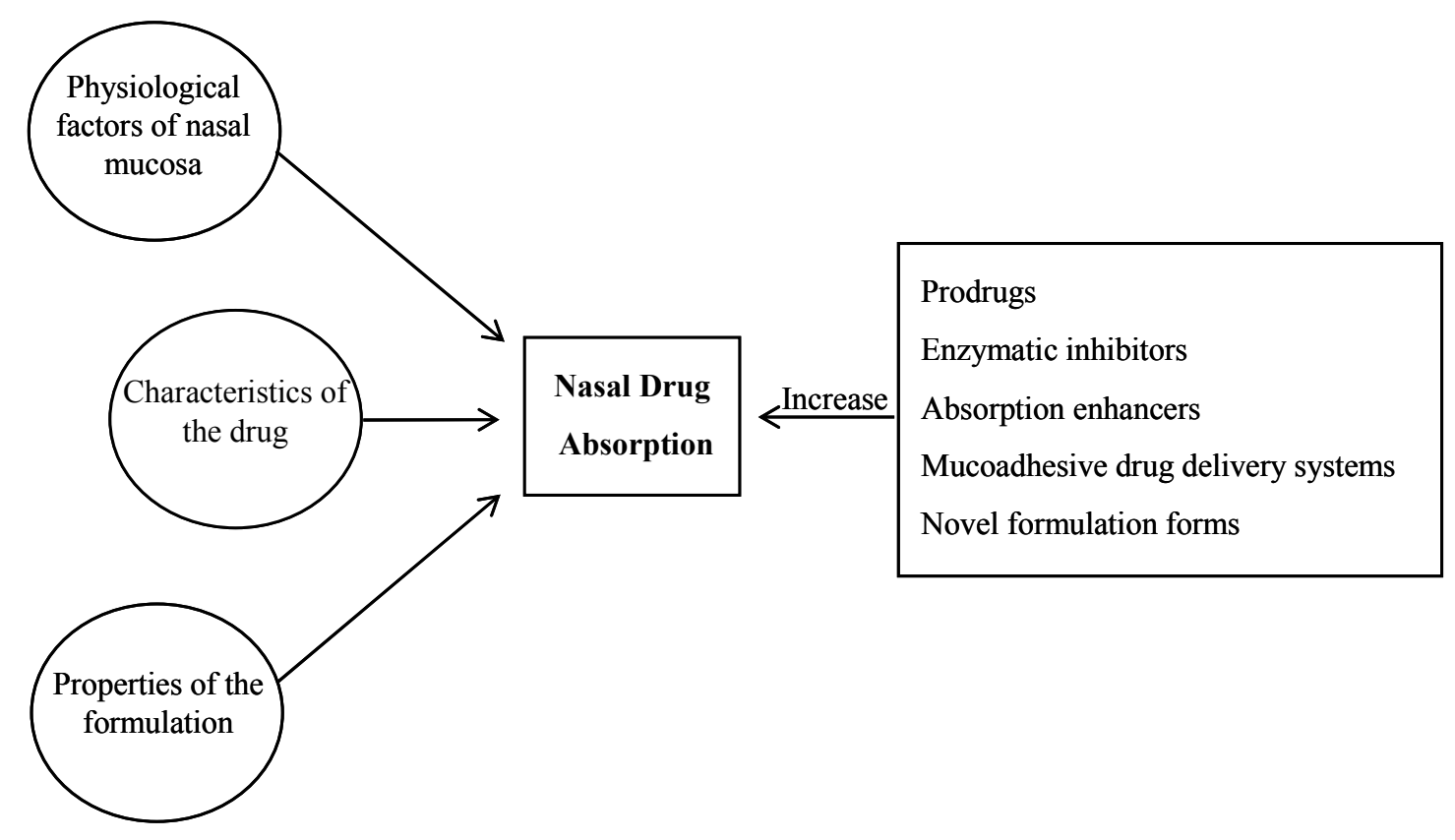

Figure 5. Factors affecting nasal drug absorption and practical strategies to overcome them.

Table 4. Common problems associated to low nasal bioavailability of drugs, challenges and possible solutions.

\begin{tabular}{|c|c|c|}
\hline Problem & Challenge & Solution \\
\hline $\begin{array}{l}\text { Poor physicochemical } \\
\text { properties of drug and/or } \\
\text { formulation }\end{array}$ & $\begin{array}{l}\text { Improve physicochemical properties of drug } \\
\text { and/or formulation }\end{array}$ & $\begin{array}{l}\text { - Prodrugs } \\
\text { - Cosolvents } \\
\text { - Cyclodextrins } \\
\text { - Pharmaceutical excipients } \\
\text { - Novel drug formulations }\end{array}$ \\
\hline \multirow[t]{3}{*}{ Enzymatic degradation } & Reduce drug affinity to nasal enzymes & - Prodrugs \\
\hline & Inhibit nasal enzymes & - Enzymatic inhibitors \\
\hline & Protect drugs from nasal enzymes & $\begin{array}{l}\text { - Prodrugs } \\
\text { - Cosolvents }\end{array}$ \\
\hline \multirow[t]{3}{*}{$\begin{array}{l}\text { Low permeability through } \\
\text { nasal membrane }\end{array}$} & Increase drug permeability and dissolution & $\begin{array}{l}\text { - Prodrugs } \\
\text { - Cosolvents }\end{array}$ \\
\hline & Modify nasal membrane & - Absorption enhancers \\
\hline & Enhance drug residence time in nasal cavity & $\begin{array}{l}\text { - Mucoadhesive systems } \\
\text { - Gelling/Viscosifying agents }\end{array}$ \\
\hline
\end{tabular}

Several approaches have been suggested to overcome these limitations, including the use of prodrugs, enzymatic inhibitors, absorption enhancers, development of mucoadhesive delivery systems and new pharmaceutical forms (Figure 5 and Table 4).

\subsection{Prodrugs}

The term 'prodrug' was coined by Albert in 1951 (129) and it is used to describe compounds that undergo biotransformation prior to exhibiting their pharmacological effect. Over the years, prodrugs have been used to overcome drugs' bad taste, poor solubility, insufficient stability, 
incomplete absorption across biological barriers and premature metabolism to inactive or toxic species (130).

Intranasal drugs are commonly administered as solutions or as powder formulations which need to undergo a dissolution process before absorption. Lipophilic drugs easily pass through biomembranes, however they are poorly watersoluble. In this way, they should be administered as a prodrug with higher hydrophilic character in order to make possible the production of an aqueous nasal formulation with a suitable concentration. Once in the blood stream, the prodrug must be quickly converted to the parent drug. For instance, L-Dopa is poorly soluble in water, so it is very difficult to develop a corresponding intranasal aqueous formulation with an effective dose. Kao et al. (101) produced various prodrugs of L-Dopa and observed that their solubility enhanced significantly in comparison with the parent drug (Figure 6), allowing, hence, the development of adequate nasal formulations. Furthermore, their nasal administration resulted in a rapid and complete absorption to the systemic circulation, where quick conversion to L-Dopa takes place. Similar results were obtained for testosterone which is also poorly water-soluble (127).

In contrast, very hydrophilic polar drugs may not have ability to cross biomembranes. Thereby, if they are administered as prodrugs with higher lipophilic character, the penetration through the membrane may increase (131). Some researches have also used the prodrug approach for improving enzymatic stability of drugs. For example, Yang et al. (63) stated that L-aspartate$\beta$-ester prodrug of acyclovir was more permeable and less labile to enzymatic hydrolysis than its parent drug. In addition, the potential use of prodrugs to protect peptide drugs from nasal enzymatic degradation has been discussed and suggested as a powerful strategy to increase the bioavailability of peptides when intranasally administered $(11,13,100)$.

An alternative approach to the use of prodrugs in order to increase drug solubility is the use of co-solvents (13). Co-solvents most used in intranasal formulations include glycerol, ethanol, propyleneglycol and polyethylene glycol and may be of the most importance since they are nontoxic, pharmaceutically acceptable and nonirritant to nasal mucosa.

\section{L-Dopa prodrugs}

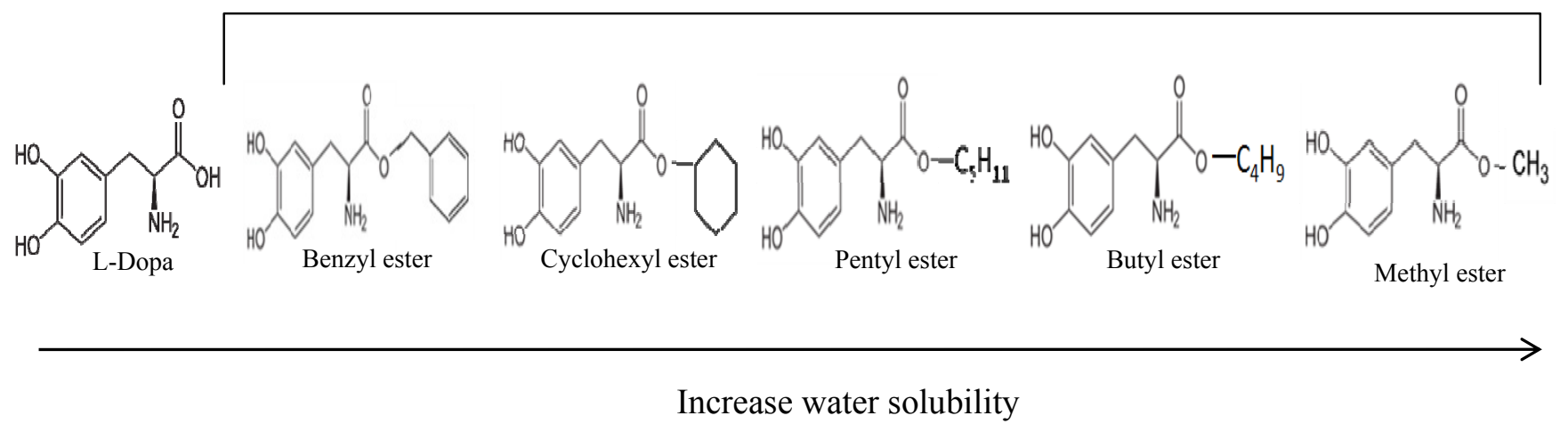

Figure 6. L-Dopa and its water soluble prodrugs (101).

\subsection{Enzymatic inhibitors}

Nasal mucus layer and nasal mucosa act as enzymatic barriers during nasal drug delivery, because they have a wide variety of enzymes. Various approaches have been used to avoid enzymatic degradation, including the use of proteases and peptidases inhibitors. For example, bestatine and comostate amylase are used as aminoptidases inhibitors and leupeptine and aprotinin as trypsine inhibitors probably involved in the degradation of calcitonin (125). Furthermore, bacitracin, amastatin, boroleucin and puromycin (124-126) have been used to avoid enzymatic degradation of drugs such as leucine enkephalin $(132,133)$ and human growth hormone (134). Finally, enzymatic inhibition can also be achieved using certain absorption 
enhancers (bile salts and fusidic acid) (13). It is demonstrated that disodium ethylenediaminetetraacetate, an absorption enhancer, reduces enzymatic degradation of beta sheet breaker peptide used for the treatment of Alzheimer's disease (135).

\subsection{Absorption enhancers}

Small and large hydrophilic drugs may be poorly permeable across nasal epithelium and may show an insufficient bioavailability. It is possible to greatly improve their absorption if they are administered in combination with absorption enhancers which induce reversible modifications on the structure of epithelial barrier. In intranasal drug delivery, absorption enhancers most used are surfactants (laureth-9), bile salts, fatty acids (taurodihydrofusidate) and polymeric enhancers (chitosan, cyclodextrins, poly-L-arginine and aminated gelatine) $(37,57,105,136-140)$.

The mechanism of action of absorption enhancers is not well known but, generally, they change the permeability of epithelial cell layer by modifying the phospholipidic bilayer, increasing membrane fluidity or opening tight junctions between epithelial cells and, thus, increasing paracellular transport (58). Although the absorption promoters enhance drug bioavailability, a direct relation between this effect and the damage caused in the membrane may sometimes exist $(141,142)$. In fact, surfactants, bile salts, fatty acids, phospholipids and lyso-phospholipids modify cell structures, leaching out proteins or even stripping off the outer layer of the mucosa $(4,7)$. On the other hand, some promoters such as chitosan, cyclodextrins and selected phospholipids present an absorption enhancing effect that greatly outweighs any modification caused in mucosa. Indeed, they act mainly by opening the tight junctions. Moreover, polymeric enhancers present high molecular weight and, hence, they are not absorbed, minimizing systemic toxicity in comparison with enhancers of low molecular weight.

A wide range of absorption enhancers are evaluated in animal models. Special caution is required when interpreting these results as they can be grossly overestimated when compared with human studies. Probably, this results from distinct architectures and morphologies of nasal cavity in different species $(4,7)$ as resumed in Table 5. Thus, during the choice of an absorption enhancer to include in an intranasal formulation, it is essential to assure a good absorption enhancing and minimal toxic effects. Considering the wide variety of absorption enhancers that may be used in intranasal administration, this review will only discuss those ones which are more used as a result of their significant enhancing effect and their low toxicity.

\subsubsection{Chitosan}

Chitosan is a linear polysaccharide biopolymer produced by deacetylation of chitin, the main component of crustacean's exoskeleton (13). Due to its biodegradability, biocompatibility and bioadhesive properties associated to a low toxicity, chitosan is widely used in intranasal formulations. It is believed that it interacts with protein kinase $\mathrm{C}$ system and opens the tight junctions between epithelial cells (98), increasing paracellular transport of polar drugs. Moreover, it interacts strongly with nasal mucus layer enhancing the contact time for the transport of the drug across the membrane (4, 143-145). Finally, chitosan also enhances the dissolution rate of low water soluble drugs $(120,128)$. Consequently, chitosan is used in several intranasal pharmaceutical forms, including powders, liquids, gels, microparticles and microspheres. For some drugs, it is well documented that the addition of chitosan to nasal formulation increases drug bioavailability. Some of the most studied drugs are insulin $(7,55)$ and morphine $(4,7,51)$.

\subsubsection{Cyclodextrins}

Cyclodextrins are cyclic oligossacharides composed of glucose units joined trough $\alpha-1,4-$ glycosidic bonds resulted from bacterial digestion of cellulose. Structurally, they have a hydrophilic outer surface and a lipophilic central cavity where apolar drugs can be included (146, 147). Cyclodextrins are used as complexing agents to improve nasal drug absorption by increasing drug solubility and stability. They can also work as absorption enhancers, since they interact with the lipophilic components of biological membranes changing their permeability $(13,35,148-150)$. Although widely used in intranasal medicinal preparations, cyclodextrins present some local and systemic toxicity. Moreover, alterations of nasal morphology, ciliary beat frequency, erythrocyte haemolysis and citotoxic effects have also been reported (151). 
Table 5. Characteristics of nasal cavity of different animal species $(26,97)$.

\begin{tabular}{llllll}
\hline Nasal Cavity & Human & Rat & $\begin{array}{c}\text { Species } \\
\text { Rabbit }\end{array}$ & Monkey & Dog \\
\hline Length $(\mathrm{cm})$ & 7.5 & 2.3 & 5.2 & 5.3 & 10.0 \\
Volume $\left(\mathrm{cm}^{3}\right)$ & 20.0 & 0.4 & 6.0 & 8.0 & 20.0 \\
Surface area $\left(\mathrm{cm}^{2}\right)$ & 150.0 & 14.0 & 61.0 & 61.6 & 220.7 \\
Olfactory area $\left(\mathrm{cm}^{2}\right)$ & 10.0 & 7.0 & 6.0 & NF & NF \\
\hline
\end{tabular}

NF, not found.

\subsubsection{Mucoadhesive drug delivery systems}

MCC is one of the most important limiting factors for nasal drug delivery, because it reduces the time allowed for drug absorption. Thus, improving nasal drug absorption can also be achieved prolonging the contact time between drug and nasal mucosa. In this way, mucoadhesive drug delivery systems have been developed $(65,89,152-154)$. Mucoadhesion implies the attachment of the drug delivery system to the mucus, involving an interaction between mucin and a synthetic or natural polymer called mucoadhesive. The sequential events that occur during this mucoadhesion include several steps. Firstly mucoadhesive systems absorb water from mucus layer and get wet and swelling. Following this, the polymer intimately penetrates into the mucus (155) and, hence, localizes the formulation in nasal cavity, enhancing the drug concentration gradient across the epithelium.

Mucoadhesives mostly used in intranasal drug delivery are chitosan, alginate and cellulose or its derivatives. Some of them may present other important characteristics which also enhance drug absorption. For example, chitosan is mucoadhesive and also causes a transient widening of epithelial tight junctions. Carbacol 934P and polycarbophil are mucoadhesive polymers that inhibit the trypsin proteolytic enzyme and, therefore, they can be used also to increase the stability of peptide drugs (155). Sodium alginate is a water-soluble, natural, linear polysaccharide which is widely used as a polymer matrix due to its non-toxicity, biocompatibility and gel formation stability. Indeed, it has the highest mucoadhesive strength compared with polymers such as polystyrene, chitosan, carboxymethylcellulose and poly(lactic acid) (155).

\subsection{Novel drug formulations}

Several claims have been made in favour of developing nasal formulations containing liposomes, microspheres and nanoparticles for intranasal drug delivery. These systems can include, besides the drug, enzymatic inhibitors, nasal absorption enhancers or/and mucoadhesive polymers in order to improve the stability, membrane penetration and retention time in nasal cavity. In fact, it is not clear if those formulations increase drug absorption by transporting encapsulated drug across the membrane or just because they enhance the nasal retention time and stability of the drug. However, their use is in widespread growth and the results have been very promising.

\subsubsection{Liposomes}

Liposomes are phospholipids vesicles composed by lipid bilayers enclosing one or more aqueous compartments and wherein drugs and other substances can be included. Liposomal drug delivery systems present various advantages such as the effective encapsulation of small and large molecules with a wide range of hydrophilicity and pKa values (64). In fact, they have been found to enhance nasal absorption of peptides such as insulin and calcitonin by increasing their membrane penetration $(156,157)$. This has been attributed to the increasing nasal retention of peptides (157), protection of the entrapped peptides from enzymatic degradation $(158,159)$ and mucosal membrane disruption (160). Jain et al. (156) incorporated insulin in liposomes coated with chitosan and carbapol and administered them intranasally to rats. The results demonstrated that this formulation was effective and that its mucoadhesive property is a viable option for a sustained release of insulin. The same work has demonstrated the usefulness of novel 
mucoadhesive multivesicular liposomes for transmucosal insulin delivery.

Moreover, liposomal drug delivery systems were also reported as useful for influenza vaccine (65) and non-peptide drugs such as nifedipine (161). Liposomes can be incorporated in different formulations. For example, Ding et al. (48) obtained a rapid onset of action and sustained delivery of levonorgestrel when it was intranasally administered as a liposome suspension. Furthermore, positive results were also found during nasal delivery of acyclovir in a liposomal gel (64). The use of a liposomal gel not only promoted the prolonged contact between the drug and the absorptive site, but also facilitated direct absorption through the nasal mucosa. These conclusions were obtained comparing liposomal formulations and free drug suspended in gel.

\subsubsection{Microspheres}

Microsphere technology has been widely applied in designing formulations for nasal drug delivery (57, 152-154, 162). Microspheres are usually based on mucoadhesive polymers (chitosan, alginate), which present advantages for intranasal drug delivery. Furthermore, microspheres may also protect the drug from enzymatic metabolism and sustain drug release, prolonging its effect $(153,162)$. Wang et al. (57) have investigated aminated gelatin microspheres as a nasal drug delivery system for insulin. They have observed a significant hypoglycemic effect when administered intranasally in dry powder form to rats, but no significant effect was achieved when given in a suspension. Gavine et al. (152) have analyzed nasal mucosa after its exposure to microspheres of alginate/chitosan containing metoclopramide. They observed open tight junctions in the epithelium and also stated that these spray-dried microspheres have promising properties as mucoadhesive nasal carriers. Many other similar studies have been carried out and positive results are found for nasal delivery of carbamazepine using chitosan microspheres (162), cyclodextrins using chitosan and alginate as mucoadhesive polymers (153) and carvedilol using alginate mucoadhesive microspheres (154).

\subsubsection{Nanoparticles}

Recently, much attention has been given to nanotechnology in many areas. Nanoparticle systems are being investigated to improve drug delivery and intranasal drug administration. Nanoparticles are solid colloidal particles with diameters raging from 1-1000 nm (163). They consist of macromolecular materials and can be therapeutically used as adjuvant in vaccines or as drug carriers, in which the active substance is dissolved, entrapped, encapsulated, adsorbed or chemically attached (163). Nanoparticles may offer several advantages due to their small size, but only the smallest nanoparticles penetrate the mucosal membrane by paracellular route and in a limited quantity because the tight junctions are in the order of 3.9-8.4 $\AA$ (98).

Controversial results are found when using nanoparticles in intranasal drug delivery $(98,164-$ 168). In fact, there are few publications wherein nanoparticle formulations don't significantly enhance the drug transport across the nasal cavity (98). The low bioavailability obtained can be due to the fact that particles are probably taken up by $\mathrm{M}$-cells in the nasal associated lymphoid tissue and, therefore, transported into the lymphatic system and blood stream $(35,98)$. In contrast, other studies have suggested that nanoparticle systems may be ideally suited for the delivery of nasal vaccines $(76,169-171)$.

\section{CONCLUSION}

Considering the widespread interest in nasal drug delivery and the potential benefits of intranasal administration, it is expected that novel nasal products will continue to reach the market. They will include not only drugs for acute and longterm diseases, but also novel nasal vaccines with better local or systemic protection against infections. The development of drugs for directly target the brain in order to attain a good therapeutic effect in CNS with reduced systemic side effects is feasible.

However, it was also stated that intranasal route presents several limitations which must be overcome to develop a successful nasal medicine. Physiological conditions, physicochemical properties of drugs and formulations are the most important factors determining nasal drug absorption. The use of prodrugs, enzymatic inhibitors, absorption enhancers, mucoadhesive drug delivery systems and new pharmaceutical formulations are, nowadays, among the mostly applied strategies. Each drug is one particular case and, thus, the relationship between the drug characteristics, the strategies considered and the permeation rate is essential. 
The era of nasal drug delivery is growing. However, new efforts are needed to make this route of delivery more efficient and popular.

\section{ACKNOWLEDGEMENTS}

This work was supported by Fundação para a Ciência e a Tecnologia, POPH-QREN (SFRH/BD/45145/2008), Portugal.

\section{REFERENCES}

1. Stoner CL, Cleton A, Johnson K, Oh DM, Hallak H, Brodfuehrer J, Surendran $\mathrm{N}$, Han HK. Integrated oral bioavailability projection using in vitro screening data as a selection tool in drug discovery. Int J Pharm, 2004; 269:241-249.

2. Hou T, Wang J, Zhang W, Xu X. ADME evaluation in drug discovery. 7. Prediction of oral absorption by correlation and classification. J Chem Inf Model, 2007; 47:208-218.

3. Dressman JB, Thelen K, Jantratid E. Towards quantitative prediction of oral drug absorption. Clin Pharmacokinet, 2008; 47:655-667.

4. Illum L. Nasal drug delivery: possibilities, problems and solutions. J Control Release, 2003; 87:187-198.

5. Yamaya M, Finkbeiner WE, Chun SY, Widdicombe JH. Differentiated structure and function of cultures from human tracheal epithelium. Am J Physiol, 1992; 262:L713L724.

6. Romeo VD, Meireles J, Sileno AP, Pimplaskar HK, Behl CR. Effects of physicochemical properties and other factors on systemic nasal delivery. Adv Drug Deliv Rev, 1998; 29:89-116.

7. Illum L. Nasal drug delivery: new developments and strategies. Drug Discov Today, 2002; 7:1184-1189.

8. Graff LC, Pollock GM. Nasal drug administration: potential for targeted central nervous system delivery. J Pharm Sci, 2005; 94:1187-1195.

9. Leonard AK, Sileno AP, Brandt GC, Foerder CA, Quay SC, Costantino HR. In vitro formulation optimization of intranasal galantamine leading to enhanced bioavailability and reduced emetic response in vivo. Int J Pharm, 2007; 335:138-146.

10. Mygind N, Dahl R. Anatomy, physiology and function of the nasal cavities in health and disease. Adv Drug Deliv Rev, 1998; 29:3-12.

11. Arora P, Sharma S, Garg S. Permeability issues in nasal drug delivery. Drug Discov Today, 2002; 7:967-975.
12. Rapoport A, Winner P. Nasal delivery of antimigraine drugs: clinical rationale and evidence base. Headache, 2006; 46:S192S201.

13. Costantino HR, Illum L, Brandt G, Johnson PH, Quay SC. Intranasal delivery: Physicochemical and therapeutic aspects. Int $\mathrm{J}$ Pharm, 2007; 337:1-24.

14. Hosoya K, Kubo H, Natsume H, Sugibayashi $\mathrm{K}$, Morimoto Y. Evaluation of enhancers to increase nasal absorption using Ussing chamber technique. Biol Pharm Bull, 1994; 17:316-322.

15. Kaliner MA. A novel and effective approach to treating rhinitis with nasal antihistamines. Ann Allergy Asthma Immunol, 2007; 99:383390.

16. Costantino HR, Leonard AK, Brandt G, Johnson PH, Quay SC. Intranasal administration of acetylcholinesterase inhibitors. BMC Neurosci, 2008; 9:S3-S6.

17. Gupta S, Moulik SP. Biocompatible microemulsions and their prospective uses in drug delivery. J Pharm Sci, 2008; 97:22-45.

18. Jogani V, Jinturkar K, Vyas $\mathrm{T}$, Misra A. Recent patents review on intranasal administration for CNS drug delivery. Recent Pat Drug Deliv Formul, 2008; 2:25-40.

19. Hanson LR, Frey WH 2nd. Intranasal delivery bypasses the blood-brain barrier to target therapeutic agents to the central nervous systems and treat neurodegenerative disease. BMC Neurosci, 2008; 9:S3-S5.

20. Shelley K, Paech MJ. The clinical applications of intranasal opioids. Curr Drug Deliv, 2008; 5:55-58.

21. $\mathrm{Wu} \mathrm{H}, \mathrm{Hu} \mathrm{K}$, Jiang $\mathrm{X}$. From nose to brain: understanding transport capacity and transport rate of drugs. Expert Opin Drug Deliv, 2008; 5:1159-1168.

22. Mann JF, Acevedo R, Campo JD, Pérez O, Ferro VA. Delivery systems: a vaccine strategy for overcoming mucosal tolerance? Expert Rev Vaccines, 2009; 8:103-112.

23. Wermeling DP. Intranasal delivery of antiepileptic medications for treatment of seizures. Neurotherapeutics, 2009; 6:352-358.

24. Dekker M., Encyclopedia of Pharmaceutical Technology. Informa HealthCare, New York, USA, 2002.

25. Chien YW, Chang SF. Intranasal drug delivery for systemic medications. Crit Rev Ther Drug Carrier Syst, 1987; 4:67-194.

26. Wynsberghe D.V., Noback R.C., Carola R., Human anatomy and physiology, McGrawHill Companie, UK, 1994.

27. Stevens A., Lowe J., Human histology, Mosby, Philadelphia, USA, 1997.

28. Merkus FW, Verhoef JC, Schipper NG, Marttin E. Nasal mucociliary clearance 
as a factor in nasal drug delivery. Adv Drug Deliv Rev, 1998; 29:13-38.

29. Agu, R.U., Ugwoke, M.I., Drug Absorption Studies:In situ, In vitro and In silico models, chapter 5, Springer, USA, 2007.

30. Kimbell JS, Gross EA, Richardson RB, Conolly RB, Morgan KT. Correlation of regional formaldehyde flux predictions with the distribution of formaldehyde-induced squamous metaplasia in F344 rat nasal passages. Mutat Res, 1997; 380:143-154.

31. Gosau M, Rink D, Driemel O, Draenert FG. Maxillary sinus anatomy: a cadaveric study with clinical implications. Anat Rec, 2009; 292:352-354.

32. Dondeti P, Zia H, Needham TE. Bioadhesive and formulation parameters affecting nasal absorption. Int J Pharm, 1996; 127:115-133.

33. Verdugo P. Goblet cells secretion and mucogenesis Annu Rev Physiol, 1990; 52:157-176.

34. Lethem MI. The role of tracheobronchial mucus in drug administration to the airways. Adv Drug Deliv, 1993; 11:19-27.

35. Dae-Duk Ki, Drug Absorption Studies: In situ, In vitro and In silico models, chapter 9, Springer, USA, 2007.

36. Baumann U. Mucosal vaccination against bacterial respiratory infections. Expert Rev Vaccines, 2008; 7:1257-1276.

37. Charlton S, Jones NS, Davis SS, Illum L. Distribution and clearance of bioadhesive formulations from the olfactory region in man: Effect of polymer type and nasal delivery device. Eur J Pharm Sci, 2007; 30:295-302.

38. Wattanakumtornkul S, Pinto AB, Williams DB. Intranasal hormone replacement therapy. Menopause, 2003; 10:88-98.

39. Martindale: The complete drug reference (http://www.medicinescomplete.com/mc/mart indale/2007)

40. Salib RJ, Howarth PH. Safety and tolerability profiles of intranasal antihistamines and intranasal corticosteroids in the treatment of allergic rhinitis. Drug Saf, 2003; 26:863-893.

41. Desrosiers MY, Salas-Prato M. Treatment of chronic rhinosinusitis refractory to other treatments with topical antibiotic therapy delivered by means of a large-particle nebulizer: Results of a controlled trial. Otolaryngol Head Neck Surg, 2001; 125:265269.

42. Vaughan WC, Carvalho G. Use of nebulized antibiotics for acute infections in chronic sinusitis. Otolaryngol Head Neck Surg, 2002; 127:558-568.

43. Ramadan HH, Sanclement JA, Thomas JG. Chronic rhinosinusitis and biofilms.
Otolaryngol Head Neck Surg, 2005; 132:414417.

44. Sanderson AR, Leid JG, Hunsaker D. Bacterial biofilms on the sinus mucosa of human subjects with chronic rhinosinusitis. Laryngoscope, 2006; 116:1121-1126.

45. Desrosiers M, Bendouah Z, Barbeau J. Effectiveness of topical antibiotics on Staphylococcus aureus biofilm in vitro. Am J Rhinol, 2007; 21:149-153.

46. Lim M, Citardi MJ, Leong JL. Topical antimicrobials in the management of chronic rhinosinusitis: A systematic review. Am J Rhinol, 2008; 22:381-389.

47. Furubayashi T, Kamaguchi A, Kawaharada K, Masaoka Y, Kataoka M, Yamashita S, Higashi Y, Sakane T. Evaluation of the Contribution of the Nasal Cavity and Gastrointestinal Tract to Drug Absorption Following Nasal Application to Rats. Biol Pharm Bull, 2007; 30:608-611.

48. Ding WX, Qi XR, Fu Q, Piao HS. Pharmacokinetics and pharmacodynamics of sterylglucoside-modified liposomes for levonorgestrel delivery via nasal route. Drug Deliv, 2007; 14:101-104.

49. Heidari A, Sadrai H, Varshosaz J. Nasal delivery of insulin using bioadhesive chitosan gels. Drug Deliv, 2006; 13:31-38.

50. Ugwoke MI, Kaufmann G, Verbeke N, Kinget R. Intranasal bioavailability of apomorphine from carboxymethylcellulose-based drug delivery systems. Int J Pharm, 2000; 202:125131.

51. Stoke DG, Reber KR, Waltzman LS, Erns C, Hamilton D, Gawareck D, Mermelstein F, McNicol E, Wright C, Carr DB. Analgesic efficacy and safety of morphine-chitosan nasal solution in patients with moderate to severe pain following orthopedic surgery. Pain Med, 2008; 9:3-12.

52. Kilian N, Müller DG. The effect of a viscosity and an absorption enhancer on the intra nasal absorption of metoprolol in rats. Int J Pharm, 1998; 163:211-217.

53. Patil SB, Sawant KK. Development, optimization and in vitro evaluation of alginate mucoadhesive microspheres of carvedilol for nasal delivery. J Microencapsul, 2008; 9:1-12.

54. Rathnam G, Narayanan N, Ilavarasan R. Carbopol-based gels for nasal delivery of progesterone. AAPS Pharm Sci Tech, 2008; 9:1078-1082.

55. Yu S, Zhao Y, Wu F, Zhang X, Lü W, Zhang $\mathrm{H}$, Zhang Q. Nasal insulin delivery in the chitosan solution: in vitro and in vivo studies. Int J Pharm, 2004; 281:11-23. 
56. Varshosaz J, Sadrai H, Heidari A. Nasal delivery of insulin using bioadhesive chitosan gels. Drug Deliv, 2006; 13:31-38.

57. Wang J, Tabata Y, Morimoto K. Aminated gelatin microspheres as a nasal delivery system for peptide drugs: Evaluation of in vitro release and in vivo insulin absorption in rats. J Control Release, 2006; 113:31-37.

58. Karasulu E, Yavasoğlu A, Evrensanal Z, Uyanikgil Y, Karasulu HY. Permeation studies and histological examination of sheep nasal mucosa following administration of different nasal formulations with or without absorption enhancers. Drug Deliv, 2008; 15:219-225.

59. Onischuk AA, Tolstikova TG, Sorokina IV. Anti-inflammatory effect from indomethacin nanoparticles inhaled by male mice. J Aerosol Med Pulm Drug Deliv, 2008; 21:231-243.

60. Leykin Y, Casati A, Rapotec A. A prospective, randomized, double-blind comparison between parecoxib and ketorolac for early postoperative analgesia following nasal surgery. Minerva Anestesiol, 2008; 74:475-479.

61. Moodie JE, Brown CR, Bisley EJ. The safety and analgesic efficacy of intranasal ketorolac in patients with postoperative pain. Anesth Analg., 2008; 107:2025-2031.

62. Shao Z, Park GB, Krishnamoorthy R, Mitra AK. The physicochemical properties, plasma enzymatic hydrolysis, and nasal absorption of acyclovir and its 2'-ester prodrugs. Pharm Res, 1994; 11:237-242.

63. Yang C, Gao H, Mitra AK. Chemical stability, enzymatic hydrolysis, and nasal uptake of amino acid ester prodrugs of acyclovir. J Pharm Sci, 2001; 90:617-624.

64. Alsarra IA, Hamed AY, Alanazi FK. Acyclovir liposomes for intranasal systemic delivery: development and pharmacokinetics evaluation. Drug Deliv, 2008; 15:313-321.

65. Alsarra IA, Hamed AY, Mahrous GM, El Maghraby GM, Al-Robayan AA, Alanazi FK. Mucoadhesive polymeric hydrogels for nasal delivery of Acyclovir. Drug Dev Ind Pharm, 2009; 35:352-62.

66. Huang J, Garmise RJ, Crowder TM, Mar K, Hwang CR, Hickey AJ, Mikszta JA, Sullivan VJ. A novel dry powder influenza vaccine and intranasal delivery technology: induction of systemic and mucosal immune responses in rats. Vaccine, 2004; 23:794-801.

67. Sharma S, Mukkur TKS, Benson HA, Chen Y. Pharmaceutical aspects of intranasal delivery of vaccines using particulate systems. J Pharm Sci, 2009; 98:812-43.

68. Slutter B, Hagenaars N, Jiskoot W. Rational design of nasal vaccines. J Drug Target, 2008; 16:1-17.
69. Langley JM, Halperin SA, McNeil S, Smith B, Jones T, Burt D, Mallett CP, Lowell GH, Fries L. Safety and immunogenicity of a Proteosome - trivalent inactivated influenza vaccine, given nasally to healthy adults. Vaccine, 2006; 24:1601-1608.

70. Van Kampen KR, Shi Z, Gao P, Zhang J, Foster KW, Chen DT, Marks D, Elmets CA, Tang DC. Safety and immunogenicity of adenovirus-vectored nasal and epicutaneous influenza vaccines in humans. Vaccine, 2005; 23:1029-1036.

71. Drabick JJ, Brandt BL, Moran EE, Saunders NB, Shoemaker DR, Zollinger WD. Safety and immunogenicity testing of an intranasal group B meningococcal native outer membrane vesicle vaccine in healthy volunteers.Vaccine, 2000; 18:160-172.

72. Belshe RB, Newman FK, Anderson EL, Wright PF, Karron RA, Tollefson S, Henderson FW, Meissner HC, Madhi S, Roberton D, Marshall H, Loh R, Sly P, Murphy B, Tatem JM, Randolph V, Hackell J, Gruber W, Tsai TF. Evaluation of combined live, attenuated respiratory syncytial virus and parainfluenza 3 virus in infants and young children. J Infect Dis, 2004; 190:2096-2103.

73. Greenberg DP, Walker RE, Min-Shi L, Reisinger KS. A bovine parainfluenza virus type 3 vaccine is safe and immunogenic in early infancy. J Infect Dis, 2005; 191:11161122.

74. Brave A, Hallengard D, Schroder U, Blomberg P, Wahren B, Hinkula J. Intranasal immunization of young mice with a multigene HIV-1 vaccine in combination with the N3 adjuvant induces mucosal and systemic immune responses. Vaccine, 2008; 26:50755078.

75. Borges O, Cordeiro-da-Silva A, Tavares J, Santarém N, de Sousa A, Borchard G, Junginger HE. Immune response by nasal delivery of hepatitis B surface antigen and codelivery of a CpG ODN in alginate coated chitosan nanoparticles. Eur J Pharm Biopharm, 2008; 69:405-416.

76. Graff CL, Zhao R, Pollack GM. Pharmacokinetics of substrate uptake and distribution in murine brain after nasal instillation. Pharm Res, 2005; 22:235-244.

77. Vyas TK, Shahiwala A, Marathe S, Misra A. Intranasal drug delivery for brain targeting. Curr Drug Deliv, 2005; 2:165-175.

78. Pardrige WM. Blood brain barrier biology and methodology. J Neurovirol, 1999; 5:55565569.

79. Illum L. Transport of drugs from the nasal cavity to the central nervous system. Eur J Pharm Sci, 2000; 11:1-18. 
80. Graff CL, Pollack GM. P-Glycoprotein attenuates brain uptake of substrates after nasal instillation. Pharm Res, 2003; 20:12251230.

81. Graff CL, Pollack GM. Functional Evidence for P-glycoprotein at the Nose-Brain Barrier. Pharm Res, 2005; 22:86-93.

82. Westin U, Piras E, Jansson B, Bergström U, Dahlin M, Brittebo E, Björk E. Transfer of morphine along the olfactory pathway to the central nervous system after nasal administration to rodents. Eur J Pharm Sci, 2005; 24:565-573.

83. Thorne RG, Pronk GJ, Padmanabhan V, Frey II WH. Delivery of insulin-like growth factorI to the rat brain and spinal cord along olfactory and trigeminal pathways following intranasal administration. Neuroscience 2005; 127:481-496.

84. Chow HH, Anavy N, Villalobos A. Direct Nose-Brain Transport of benzoylecgonine following intranasal administration in rats. $\mathrm{J}$ Pharm Sci, 2001; 90:1729-1735.

85. Dufes C, Olivier JC, Gaillard F, Gaillard A, Couet W, Muller JM. Brain delivery of vasoactive intestinal peptide (VIP) following nasal administration to rats. Int $\mathrm{J}$ Pharm, 2003; 255:87-97.

86. Zhang QZ, Jiang XG, Wu CH. Distribution of nimodipine in brain following intranasal administration in rats. Acta Pharmacol Sin, 2004; 25:522-527.

87. Doyle KP, Yang T, Lessov NS, Ciesielski TM, Stevens SL, Simon RP, King JS, StenzelPoore MP. Nasal administration of osteopotin peptide mimetics confers neuroprotection in stroke. J Cereb Blood Flow Metab, 2008; 28:1235-1248.

88. Jogani VV, Shah PJ, Mishra P, Mishra AK, Misra AR. Nose-to-brain delivery of tacrine. J Pharm Pharmacol, 2007; 59:1199-1205.

89. Jogani VV, Shah PJ, Mishra P, Mishra AK, Misra AR. Intranasal mucoadhesive microemulsion of tacrine to improve brain targeting. Alzheimer Dis Assoc Disord, 2008; 22:116-124.

90. Hashizume R, Ozawa T, Gryaznov SM, Bollen AW, Lamborn KR, Frey 2nd WH, Deen DF. New therapeutic approach for brain tumors: Intranasal delivery of telomerase inhibitor GRN163. Neuro Oncol, 2008; 10:112-120.

91. Sakane T, Yamashita S, Yata N, Sezaki H. Transnasal delivery of 5-fluorouracil to the brain in the rat. J Drug Target, 1999; 7:233240.

92. Barakat NS, Omar SA, Ahmed AA. Carbamazepine uptake into rat brain following intra-olfactory transport. J Pharm Pharmacol, 2006; 58:63-72.
93. Yamada K, Hasegawa M, Kametani S, Ito S. Nose-to-brain delivery of TS-002, prostaglandin D2 analogue. J Drug Target, 2007; 15:59-66.

94. Van den Berg MP, Merkus P, Romeijn SG, Verhoef JC, Merkus FW. Uptake of melatonin into the cerebrospinal fluid after nasal and intravenous delivery: studies in rats and comparation with a human study. Pharm Res, 2004; 21:799-802.

95. Van den Berg MP, Verhoef JC, Romeijn SG, Merkus FW. Uptake of estradiol or progesterone into the CSF following intranasal and intravenous delivery in rats. Eur J Pharm Biopharm, 2004; 58:131-135.

96. Yang Z, Huang Y, Gan G, Sawchuk RJ. Microdialysis evaluation of the brain distribution of stavudine following intranasal and intravenous administration to rats. $\mathrm{J}$ Pharm Sci, 2005; 94:1577-1588.

97. Kaur P, K Kim. Pharmacokinetics and brain uptake of diazepam after intravenous and intranasal administration in rats and rabbits. Int J Pharm, 2008; 364:27-35.

98. Illum L, Nanoparticulate systems for nasal delivery of drugs: A real improvement over simple systems? J Pharm Sci, 2007; 96:473483.

99. McMartin C. Analysis of structural requirements for the absorption of drugs and macromolecules from the nasal cavity. J Pharm Sci, 1987; 76:535-540.

100. Huang CH, Kimura R, Nassar RB, Hussain A. Mechanism of nasal absorption of drugs. I: Physicochemical parameters influencing the rate of in situ nasal absorption of drugs in rats. J Pharm Sci, 1985; 74:608-611.

101. Kao HD, Traboulsi A, Itoh S, Dittert L, Hussain A. Enhancement of the systemic and CNS specific delivery of L-dopa by the nasal administration of its water soluble prodrugs. Pharm Res, 2000; 17:978-984.

102. Schipper N, Verhoef J, Merkus FW. The nasal mucociliary clearance: Relevance to nasal drug delivery. Pharm Res, 1991; 8:807-814.

103. Houtmeyers E, Gosselink R, Gayan-Ramirez G, Decramer M. Regulation of mucociliary clearance in health and disease. Eur Respir J, 1999 ; 13:1177-1188.

104. Afzelius B.A, The lung: Scientific Foundations, Lippincott-Raven, Philadelphia, 1997.

105. Bogdanffy MS. Biotransformation enzymes in the rodent nasal mucosa: The value of a histochemical approach. Environ Health Perspect, 1990; 85:177-186.

106. Dahl AR, Lewis JL. Respiratory tract uptake of inhalants and metabolism of xenobiotics. Annu Rev Pharmacol Toxicol, 1993; 33:383407. 
107. Mitra AK, Krishnamoorthy R. Prodrugs for nasal drug delivery. Adv Drug Deliv Rev, 1998; 29:135-146.

108. Dimova S, Brewster ME, Noppe M, Jorissen M, Augustijns P. The use of human nasal in vitro cell systems during drug discovery and development. Toxicol In Vitro, 2005; 19:107122.

109. Sarkar MA. Drug metabolism in the nasal mucosa. Pharm Res, 1992; 9:1-9.

110. Lee VH, Yamamoto A. Penetration and enzymatic barriers of peptide and protein absorption. Adv Drug Deliv Rev, 1990; 4:171-207.

111. Harris AS. Intranasal administration of peptides: nasal deposition, biological response and absorption of desmopressin. J Pharm Sci, 1986; 75:1085-1088.

112. Kandimalla KK, Donovan MD. Transport of hydroxyzine and triprolidine across bovine olfactory mucosa: role of passive diffusion in the direct nose-to-brain uptake of small molecules. Int J Pharm, 2005; 302:133-144.

113. Christrup LL, Foster D, Popper LD. Pharmacokinetics, Efficacy, and Tolerability of Fentanyl Following Intranasal Versus Intravenous Administration in Adults Undergoing Third-Molar Extraction: A Randomized, Double-Blind, Double-Dummy, Two-Way, Crossover Study. Clin Ther, 2008; 30:469-481.

114. Corbo DC. Characterization of the barrier properties of mucosal membranes. J Pharm Sci, 1990; 79:202-206.

115. Donovan M, Flynn G, Amidon G. Absorption of polyethylene glycols 600 through 2000: the molecular weight dependence of gastrointestinal and nasal absorption. Pharm Res, 1990; 7:863-868.

116. Fisher A, Illum L, Davis S, Schacht E. Diiodo-L-tyrosine labelled dextrans as molecular size markers of nasal absorption in the rat. J Pharm Pharmacol, 1992; 44:550554.

117. Katdare A., Chaubal M.V., Excipient Development for Pharmaceutical Biotechnology and Drug Delivery Systems. Taylor \& Francis Group, LLC, USA, 2006.

118. Corbo DC. Drug absorption through mucosal membranes: effect of mucosal route and penetrant hydrophilicity. Pharm Res, 1989; 6:848-852.

119. Lipworth BJ, Jackson CM. Safety of inhaled and intranasal corticosteroids: lessons for the new millennium. Drug Saf, 2000; 23:11-33.

120. Washington N, Steele RJ, Jackson SJ, Bush D, Mason J, Gill DA, Pitt K, Rawlins DA. Determination of baseline human nasal $\mathrm{pH}$ and the effect of intranasally administered buffers. Int J Pharm, 2000; 198:139-146.
121. Hirai S, Yashiki T, Matsuzawa T, Mima H. Absorption of drugs from the nasal mucosa of rats. Int J Pharm, 1981; 7:317-325.

122. Hussain A.A., Bawarshi-Nassar R., Huang C.H., Transnasal Systemic Medications. Elsevier, Amsterdam, 1985.

123. Zaki NM, Awad GA, Mortada ND, Abd ElHady SS. Rapid-onset intranasal delivery of metoclopramide hydrochloride. Part I. Influence of formulation variables on drug absorption in anesthetized rats. Int J Pharm, 2006; 327:89-96.

124. Machida M. Effects of surfactants and protease inhibitors on nasal absorption of recombinant human granulocyte colonystimulating factor (rhG-CSF) in rats. Biol Pharm Bull, 1994; 17:1375-1378.

125. Morimoto K, Miyazaki M, Kakemi M. Effects of proteolytic enzyme inhibitors on nasal absorption of salmon calcitonin in rats. Int $\mathrm{J}$ Pharm, 1995; 113:1-8.

126. Bernkop-Schnurch A. Use of inhibitory agents to overcome the enzymatic barrier to perorally administered therapeutic peptides and proteins. J Control Release, 1998; 52:116.

127. Hussain AA, Al-Bayatti AA, Dakkuri A, Okochi K, Hussain MA. Testosterone 17 $\beta$ N,N-Dimethylglycinate Hydrochloride: A prodrug with a potential for nasal delivery of testosterone. J Pharm Sci, 2002; 91:785-789.

128. Pujara CP, Shao Z, Duncan MR, Mitra AK. Effects of formulation variables on nasal epithelial cell integrity: Biochemical evaluations. Int J Pharm, 1995; 114:197-203.

129. Albert A. Chemical aspects of selective toxicity. Nature, 1958; 182:421-430.

130. Higuchi T., Stella V., Prodrugs as Novel Drug Delivery Systems, American Chemical Society, Washington, DC, 1975.

131. Wang H, Hussain AA, Wedlund PJ. Nipecotic Acid: Systemic availability and brain delivery after nasal administration of nipecotic acid and n-Butyl nipecotate to rats. Pharm Res, 2005; 22:556-562.

132. Hussain MA. The use of alpha-aminoboronic acid derivatives to stabilize peptide drugs during their intranasal absorption. Pharm Res, 1989; 6:186-189.

133. Hoang VD, Uchenna AR, Mark J, Renaat K, Norbert V. Characterization of human nasal primary culture systems to investigate peptide metabolism. Int J Pharm, 2002; 238:247-256.

134. O'Hagan DT. Nasal absorption enhancers for biosynthetic human growth hormone in rats. Pharm Res, 1990; 7:772-776.

135. Greimel A, Bernkop-Schnürch A, Del Curto MD, D'Antonio M. Transport characteristics of a beta sheet breaker peptide across excised 
bovine nasal mucosa. Drug Dev Ind Pharm, 2007; 33:71-77.

136. Hersey SJ, Jackson RT. Effect of bile salts on nasal permeability in vitro. J Pharm Sci, 1987; 76:876-879.

137. Mishima M, Wakita Y, Nakano M. Studies on the promoting effects of medium chain fatty acid salts on the nasal absorption of insulin in rats. J Pharmacobiodyn, 1987; 10:624-631.

138. Baglioni C, Phipps RJ. Nasal absorption of interferon: enhancement by surfactant agents. J Interferon Res, 1990; 10:497-504.

139. Illum L, Farraj NF, Davis SS. Chitosan as a novel nasal delivery system for peptide drugs. Pharm Res, 1994; 11:1186-1189.

140. Ekelund K, Osth K, Påhlstorp C, Björk E, Ulvenlund $\mathrm{S}$, Johansson $\mathrm{F}$. Correlation between epithelial toxicity and surfactant structure as derived from the effects of polyethylynyoxide surfactants on caco-2 monolayers and pig nasal mucosa. J Pharm Sci, 2005; 94:730-44.

141. Sinswat P, Tengamnuay P. Enhancing effect of chitosan on nasal absorption of salmon calcitonin in rats: comparison with hydroxypropyl- and dimethyl- $\beta$-cyclodextrins. Int J Pharm, 2003; 257:15-22.

142. Zaki NM, Mortada ND, Awad GA, Abd ElHady SS. Rapid-onset intranasal delivery of metoclopramide hydrochloride Part II: Safety of various absorption enhancers and pharmacokinetic evaluation. Int $\mathrm{J}$ Pharm, 2006; 327:97-103.

143. Giunchedi P, Juliano C, Gavini E, Cossu M, Sorrenti M. Formulation and in vivo evaluation of chlorhexidine buccal tablets prepared using drug loaded chitosan microspheres. Eur J Pharm Biopharm, 2002; 53:233-239.

144. Maestrelli F, Zerrouk N, Chemto C, Mura P. Influence of chitosan and its glutamate and hydrochloride salts on naproxen dissolution rate and permeation across Caco-2 cells. Int $\mathrm{J}$ Pharm, 2004; 271:257-267.

145. Ravi Kumar MNV, Muzzarelli RAA, Muzzarelli C, Sashiwa H, Domb AJ. Chitosan chemistry and pharmaceutical perspectives. Chem Rev, 2004; 104:6017-6084.

146. Szejtli J. Introduction and general overview of cyclodextrin chemistry. Chem Rev, 1998; 98:1743-1754.

147. Duchêne D, Bochot A, Yu SC, Pépin C, Seiller M. Cyclodextrins and emulsions. Int J Pharm, 2003; 266:85-90.

148. Asai K, Morishita M, Katsuta H, Hosoda S, Shinomiya K, Noro M, Nagai T, Takayama K. The effects of water-soluble cyclodextrins on the histological integrity of the rat nasal mucosa. Int J Pharm, 2002; 246:25-35.
149. Babu RJ, Dayal P, Singh M. Effect of cyclodextrins on the complexation and nasal permeation of melatonin. Drug Deliv, 2008; 15:381-388.

150. Jug M, Becirevic-Lacan M. Development of a Cyclodextrin-Based Nasal Delivery System for Lorazepam. Drug Dev Ind Pharm, 2008; 34:817-826.

151. Merkus FW, Verhoef JC, Marttin E, Romeijn SG, Van der Kuy PH, Hermens WA, Schipper NG. Cyclodextrins in nasal drug delivery. Adv Drug Deliv Rev, 1999; 36:41-57.

152. Gavini E, Rassu G, Sanna V, Cossu M, Giunchedi P. Mucoadhesive microspheres for nasal administartion of an antiemetic drug, metoclopramide: in-vitro/ex-vivo studies. J Pharm Pharmacol, 2005; 57:287-294.

153. Gavini E, Rassu G, Haukvik T, Lanni C, Racchi M, Giunchedi P. Mucoadhesive microspheres for nasal administration of cyclodextrins. J Drug Target, 2008; 17:168179.

154. Patil SB, Sawant KK. Development, optimization and in vitro evaluation of alginate mucoadhesive microspheres of carvedilol for nasal delivery. J Microencapsul, 2008; iFirst:1-12.

155. Ugwoke MI, Agu RU, Verbeke N, Kinget R. Nasal mucoadhesive drug delivery: Background, applications, trends and future perspectives. Adv Drug Deliv Rev, 2005; 57:1640-1665.

156. Jain AK, Chalasani KB, Khar RK, Ahmed FJ, Diwan PV. Muco-adhesive multivesicular liposomes as an effective carrier for transmucosal insulin delivery. J Drug Target, 2007;15:417-427.

157. Law SL, Huang KJ, Chou VHY, Cherng JY. Enhancement of nasal absorption of calcitonin loaded in liposomes. J Liposome Res, 2001; 11:164-174.

158. Murramatsu K, Maitani Y, Takayama K, Nagai T. The relationship between the rigidity of the liposomal membrane and the absorption of insulin after nasal administration of liposomes modified with an enhancer containing insulin in rabbits. Drug Dev Ind Pharm, 1999; 25:1099-1105.

159. Kato Y, Hosokawa T, Hayakawa E, Ito K. Influence of liposomes on tryptic digestion of insulin. Biol Pharm Bull, 1993; 16:457-461.

160. Lee VH, Yamamoto A, Kompella UB. Mucosal penetration enhancers for facilitation of peptide and protein drug absorption. Crit Rev Ther Drug Carrier Syst, 1991; 8:91-192.

161. Vyas SP, Goswami SK, Singh R. Liposomes based nasal delivery system of nifedipine: Development and characterization. Int $\mathrm{J}$ Pharm, 1995; 118:23-30. 
162. Gavini E, Hegge AB, Rassu G, Sanna V, Testa C, Pirisino G, Karlsen J, Giunchedi P. Nasal administration of Carbamazepine using chitosan microspheres: In vitro/in vivo studies. Int J Pharm, 2006; 307:9-15.

163. Tiyaboonchai W. Chitosan Nanoparticles: A Promising System for Drug Delivery. Naresuan University Journal, 2003; 11:51-66.

164. Fernandez-Urrusuno R, Calvo P, RemunanLopez C, Vila-Jato JL, Alonso MJ. Enhancement of nasal absorption of insulin using chitosan nanoparticles. Pharm Res, 1999; 16:1576-1581.

165. Fernandez-Urrusuno R, Romani D, Calvo P, Vila-Jato JL, Alonso MJ. Development of a freeze dried formulation of insulin-loaded chitosan nanoparticles intended for nasal administration. S.T.P Pharma Sciences, 1999; 9:429-436.

166. Dyer AM, Hinchcliffe M, Watts P, Castile J, Jabbal-Gill I, Nankervis R, Smith A, Illum L. Nasal delivery of insulin using novel chitosan based formulations: A comparative study in two animal models between simple chitosan formulations and chitosan nanoparticles. Pharm Res, 2002; 19:998-1008.

167. Mao S, Germershaus O, Fischer D, Linn T, Schnepf R, Kissel T. Uptake and transport of PEG-graft-trimethyl-chitosan copolymer- insulin nanocomplexes by epithelial cells. Pharm Res, 2005; 22:2058-2068.

168. Simon M, Wittmar M, Kissel T, Linn T. Insulin containing nanocomplexes formed by self assembly from biodegradable aminemodified poly(vinyl alcohol)-graft-poly(Llactide): Bioavailability and nasal tolerability in rats. Pharm Res, 2005; 22:1879-1886.

169. Jung T, Kamm W, Breitenbach A, Hungerer KL, Hundt E, Kissel T. Tetanus toxoid loaded nanoparticles from sulfobutylated poly(vinyl alcohol)- graft-poly(lactide-co-glycolide): Evaluation of antibody response after oral and nasal application in mice. Pharm Res, 2001; 18:352-360.

170. Debin A, Kravtzoff R, Vaz Santiago J, Cazales L, Sperandino S, Melber K, Janowics $Z$, Betbeder D, Moynier M. Intranasal immunization with recombinant antigens associated with new cationic particles induces strong mucosal as well as systemic antibody and CTL responses. Vaccine, 2002; 20:27522763.

171. Nagamoto T, Hattori Y, Takayama K, Maitani Y. Novel chitosan particles and chitosancoated emulsions inducing immune response via intranasal vaccine delivery. Pharm Res, 2004; 21:671-674. 